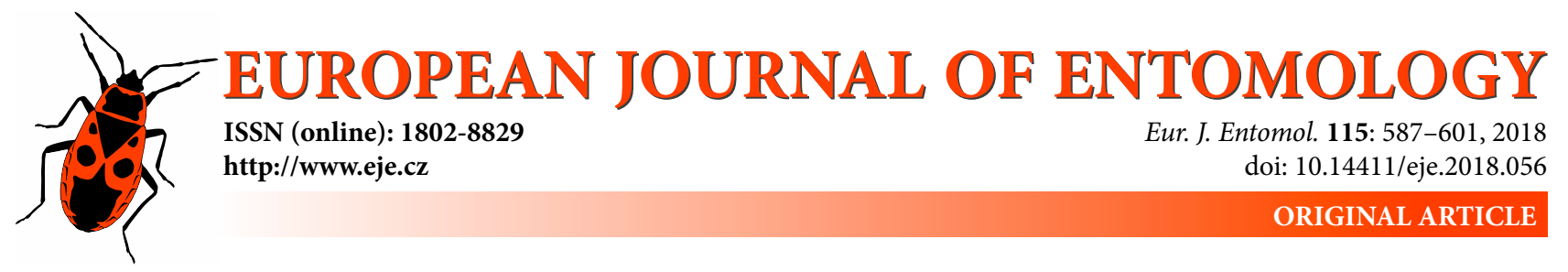

\title{
A key to genera of South American Deltocephalini (Hemiptera: Cicadellidae: Deltocephalinae) with descriptions of new taxa and nomenclatural changes
}

\author{
YANI DUAN ${ }^{1}$ and ChRISTOPHeR H. DIETRICH ${ }^{2}$ \\ ${ }^{1}$ School of Plant Protection, Anhui Agricultural University, Hefei, Anhui Province 230036, China; e-mail: duanyani@hotmail.com \\ 2 Illinois Natural History Survey, Prairie Research Institute, University of Illinois, Champaign, IL 61820, USA; \\ e-mail: chdietri@illinois.edu
}

Key words. Auchenorrhyncha, Cicadellidae, Deltocephalini, morphology, taxonomy, key to genera, new taxa, South America

\begin{abstract}
A key to genera of South American Deltocephalini Dallas, 1870 based on adult males is presented. Two new genera, each based on a single new species from Argentina are described and illustrated: Corrientesia gen. $n$. based on type species C. ochrescens sp. n. and Salnogia gen. n. based on type species S. fletcheri sp. n. A new species of Graminella DeLong, 1936, G. schrocki sp. n. from Argentina is also described and illustrated. Graminella stelliger (Berg, 1884) equals Fusanus acristylus Cheng, 1980, syn. n. A new combination, Limpica pallida (Linnavuori \& DeLong, 1979) comb. n., transferred from Reventazonia Linnavuori, 1959, is also proposed. Quaziptus Kramer, 1965, is returned from Paralimnini Distant, 1908 to Deltocephalini Dallas, 1870.
\end{abstract}

ZooBank Article LSID: BBAD822F-F76E-4BD0-89C0-685F3266A27F

\section{INTRODUCTION}

The grass-specialist leafhopper tribe Deltocephalini is a diverse group comprising 70 genera and $>600$ species distributed worldwide. Morphological and molecular phylogenetic analyses to date suggest that it is monophyletic and closely related to Paralimnini, but further taxon sampling in these large tribes and more data are needed. The two tribes together appear to be related to Tetartostylini Wagner, 1951 which also possesses the tapered clypellus and linear connective. Many genera and species of Deltocephalini are morphologically quite similar to each other. Revisions of many genera and identification keys, especially of the Neotropical fauna, are needed (Zahniser \& Dietrich, 2013). Species of this tribe are abundant in both native grasslands and agroecosystems and include vectors of plant pathogens. The group is distinguished by the linear (not Y-shaped) connective fused to the aedeagus in the male genitalia (Webb \& Viraktamath, 2009). The fauna of this tribe in South America is highly diverse. Linnavuori (1959) provided the first key to Neotropical genera of the tribe, including 16 of the genera currently placed in Deltocephalini. Cheng (1980) provided a key to the 10 genera of Deltocephalini recorded from Paraguay. The South American Deltocephalini fauna now comprises 27 genera (17 endemic) and $>150$ known endemic species, but new species continue to be discovered, especially by vacuum sampling in native grasslands (Duan et al., 2016a, b, 2017a, b, 2018a, b). Although the genus-level classification of Deltocephalini is somewhat unstable and in need of comprehensive revision, most of the recently discovered South American species have been referable to previously described genera. Here we provide a comprehensive key to South American genera of the tribe and describe two new genera to accommodate some species that do not appear to be closely related to previously described genera. We also describe a new Graminella species, propose new generic placements for two previously described species from Brazil and Paraguay, and transfer a genus previously placed in Paralimnini to Deltocephalini.

\section{MATERIAL AND METHODS}

The material studied here is deposited in the Museo de La Plata, La Plata, Argentina (MLP) and the Illinois Natural History Survey, Champaign, USA (INHS). Morphological terminology follows Dietrich (2005) and Zhang (1990). Digital photographs were taken with a QImaging Micropublisher 3.3 digital camera mounted on an Olympus BX41 stereo microscope and with a Nikon D1x digital SLR camera configured with lenses by the Microptics, Digital Lab XLT system. Photographs were modified with Adobe Photoshop CS. 


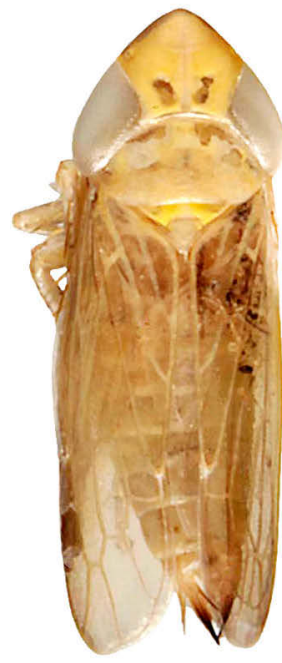

A

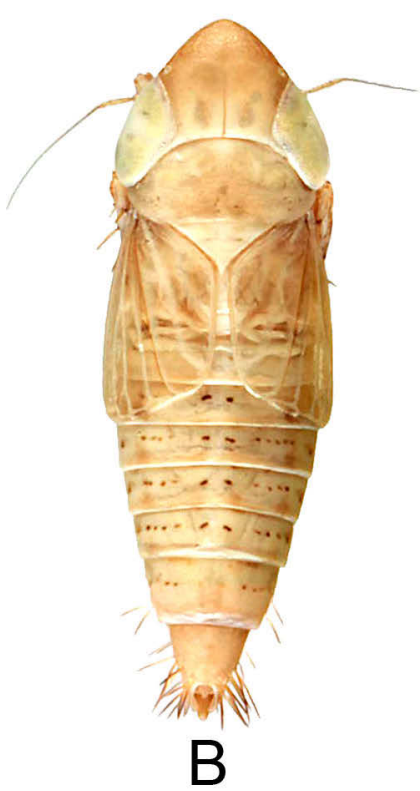

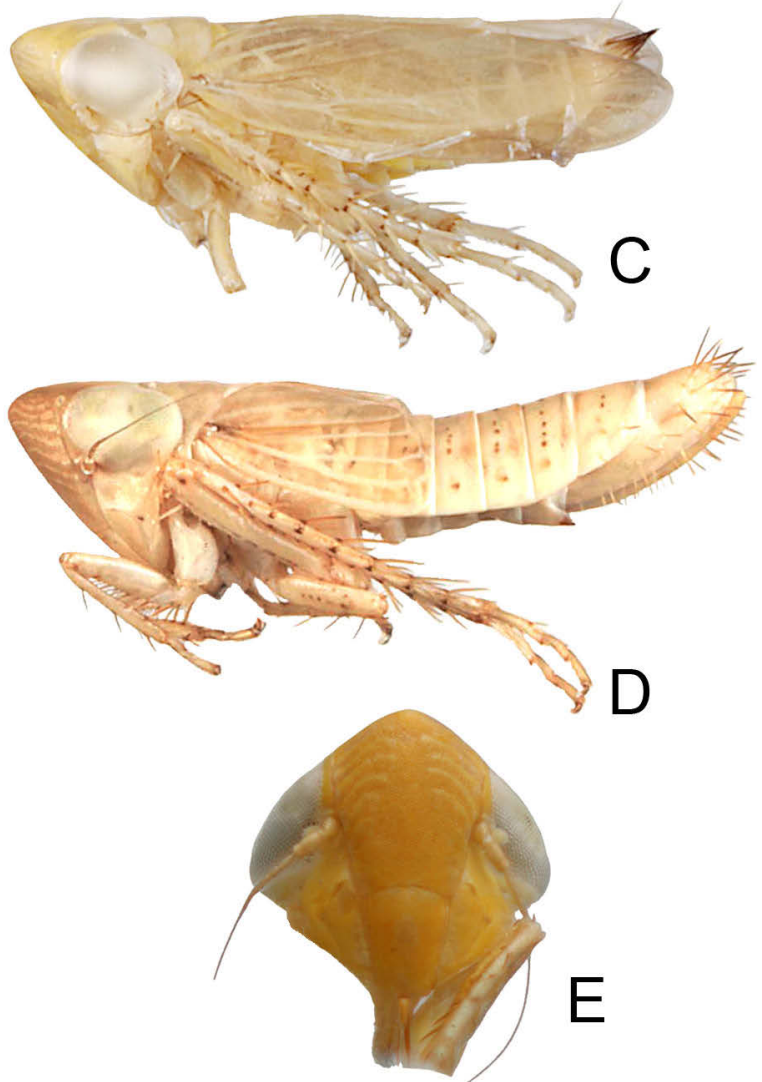

Fig. 1. Cortona minuta Oman, 1938 (A, C, E - male; B, D - female). A, B - habitus, dorsal view; C, D - habitus, lateral view; E - face (after Duan et al., 2017a).

\section{RESULTS}

\section{Key to South American genera of Deltocephalini (males)}

Note: Sanluisia Linnavuori, 1959, known from a single female specimen, is not included.

1 Forewing with two anteapical cells; male macropterous, female usually brachypterous; head, pronotum and mesonotum pale yellow or orange, without dark spots or longitudinal stripes (Fig. 1A-D) Cortona Oman, 1938
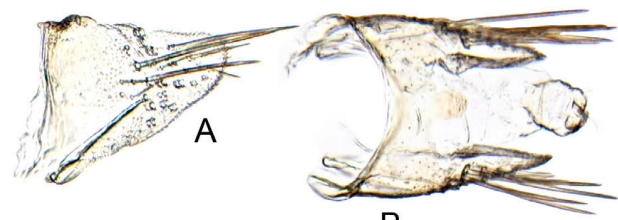

B
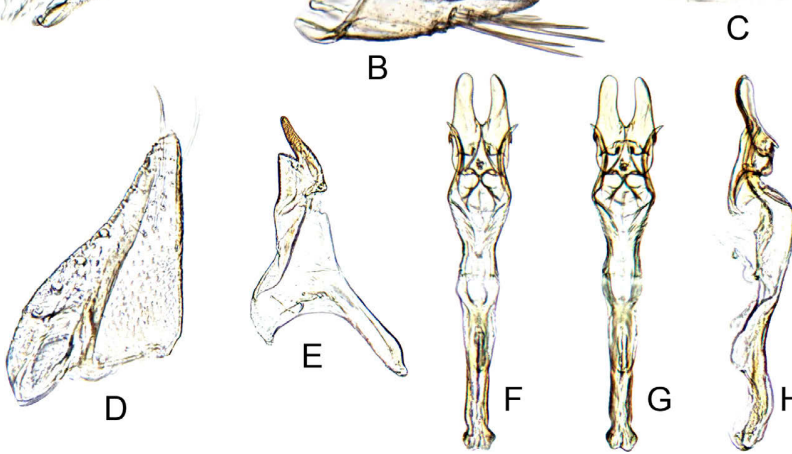

Fig. 2. Cortona minuta. A - male pygofer lobe, lateral view; B male pygofer and segments $\mathrm{X}$ and $\mathrm{XI}$, dorsal view; $\mathrm{C}$ - valve, ventral view; $\mathrm{D}$ - subgenital plate, ventral view; $\mathrm{E}$ - style, dorsal view; F, G, H - connective and aedeagus, dorsal, ventral and lateral view, respectively (after Duan et al., 2017a).
- Forewing with three anteapical cells or, if only two present, male brachypterous; head, pronotum and mesonotum usually with dark spots, longitudinal stripes and/or transverse bands of contrasting color (Fig. 5A-D) . .. 2

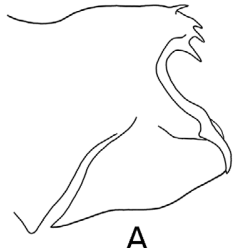

A

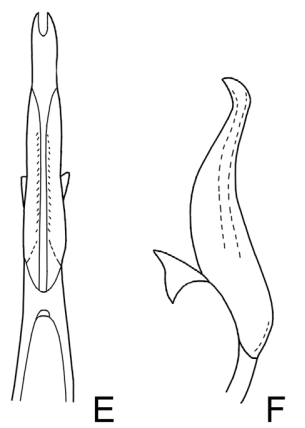

$\mathrm{F}$
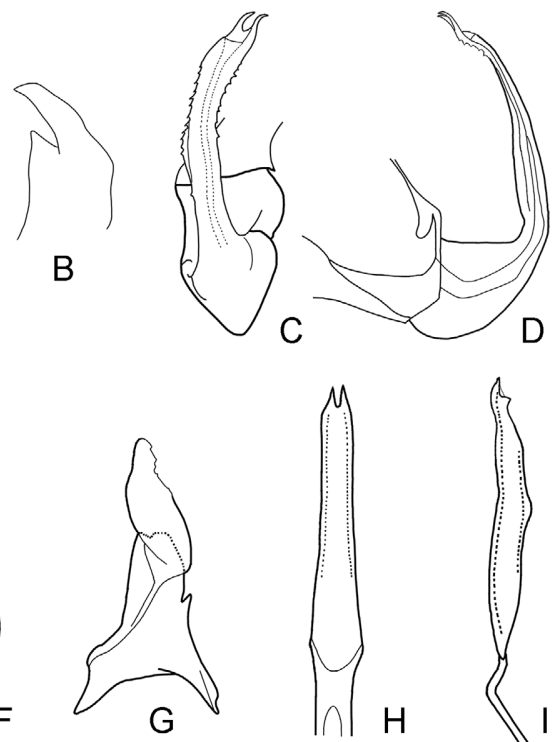

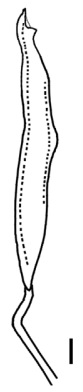

Fig. 3. A-D. Neodeltocephalus asper Linnavuori, 1959 (after Linnavuori, 1959); E, F - Bolivaia spinosa Linnavuori \& DeLong, 1979 (after Linnavuori \& DeLong, 1979b); G-I - Mattogrossus colonoides (Linnavuori, 1959) (after Linnavuori, 1959). A - male pygofer lobe, median view; $B$ - apex of style; $C, E, H$ - aedeagus, ventral view; D, F, I- aedeagus, lateral view; G - style. 

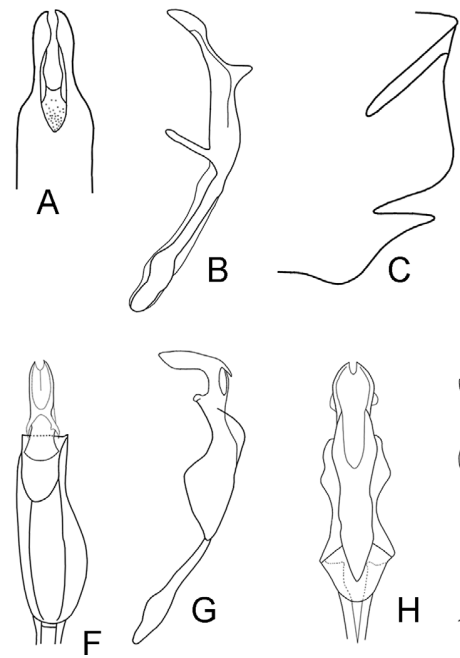
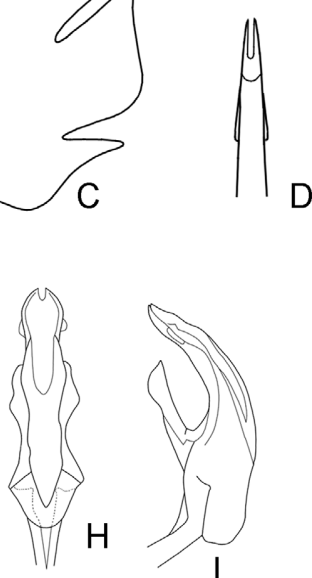
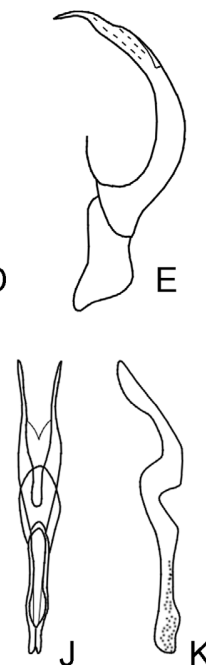

Fig. 4. A, B - Amblysellus punctatus (Osborn \& Ball, 1898) (after Kramer, 1971); C-E - Unerus colonus (Uhler, 1895) (after Freytag, 1983); F, G - Toldoanus marginellus (Osborn, 1923) (after Linnavuori, 1959); H, I - Reventazonia atrifrons Linnavuori, 1959 (after Linnavuori, 1959); J, K - Limpica forcata (after Cheng, 1980). A, D - apex of aedeagus, ventral view; B, E, G, K - connective and aedeagus, lateral view; $C$ - posterior margin of male pygofer lobe, lateral view (without macrosetae); F, $\mathrm{H}$ - aedeagus, ventral view; $\mathrm{I}$ - aedeagus, lateral view; $\mathrm{J}$ - connective and aedeagus, ventral view.
2 Aedeagus without long paired basal or distal processes; short paired or unpaired teeth or flanges (each shorter than its basal width) or longitudinal cleft that separates shaft into left and right lobes distally may be present (Fig. 26E, F)................. 3

- Aedeagus with slender, paired or unpaired basal or distal processes (in addition to sides of distal longitudinal cleft, when cleft present), each process longer than its basal width (usually much longer) (Fig. 20E, F)

3 Aedeagus apex with distinct median longitudinal cleft in posterior or ventral view (Fig. 3H) ........................................... 4

- Aedeagus with apex entire, without median cleft (Fig. 18E).

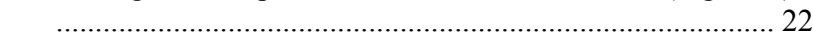

4 Pygofer with large sclerotized process or processes, lobe emarginate distally (Fig. 3A).

- Pygofer without large sclerotized processes, lobe rounded distally, at most with small tooth or thickening on posteroventral margin (Fig. 26A).

5 Aedeagus asymmetrical, lateral margins of shaft serrate (Fig. 3C, D) ........................... Neodeltocephalus Linnavuori, 1959

- Aedeagus symmetrical, lateral margins of shaft entire (Fig. $3 \mathrm{E}, \mathrm{F})$ Bolivaia Linnavuori \& DeLong, 1979

6 Aedeagal shaft elongate, slender, tubular through most of length, sometimes with pair of short preapical ventrolateral flanges (Fig. 4D, E); crown usually with pair of large black lateral preapical spots.

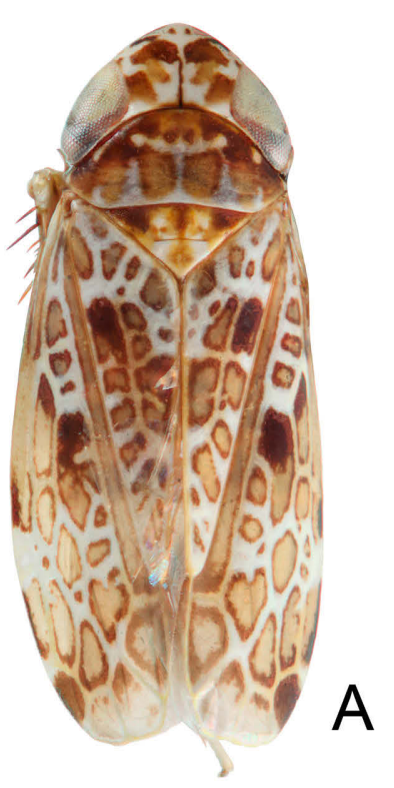

A
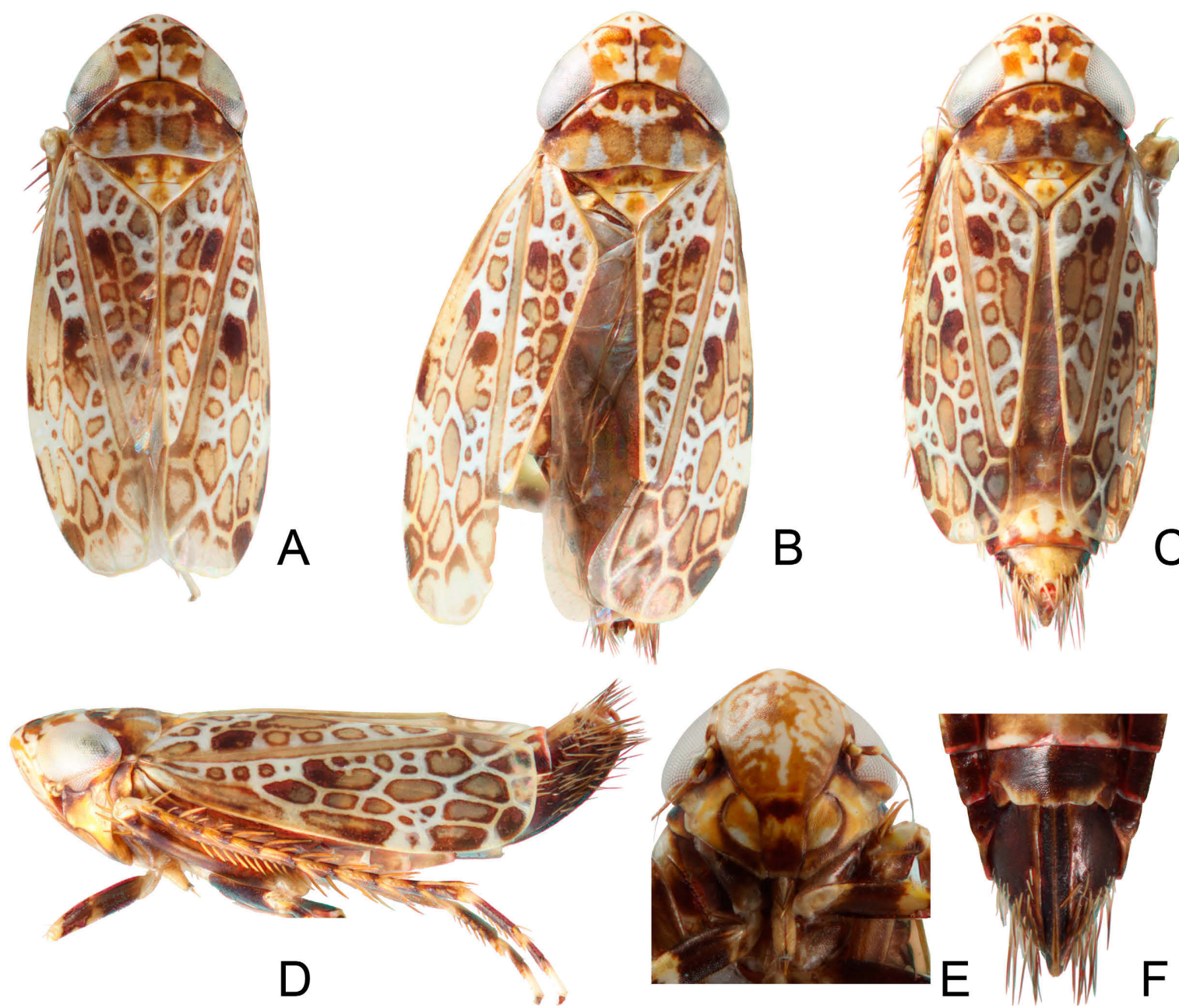

Fig. 5. Amplicephalus (Nanctasus) paralbivenosus Duan \& Dietrich, 2018 (A - male; B-F - female). A, B, C - habitus, dorsal view; D habitus, lateral view; $\mathrm{E}-$ face; $\mathrm{F}-$ the end of female abdomen, ventral view (after Duan et al., 2018a). 

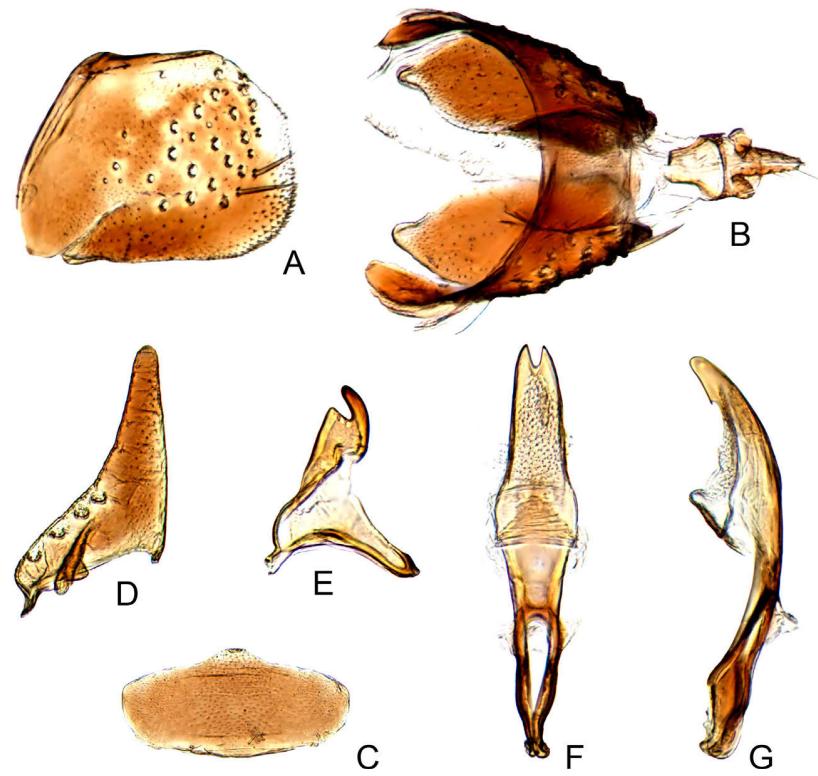

Fig. 6. Amplicephalus (Nanctasus) paralbivenosus. A - male pygofer lobe, lateral view; $\mathrm{B}$ - male pygofer and segments $\mathrm{X}$ and $\mathrm{XI}$, dorsal view; $C$ - valve, ventral view; $D$ - subgenital plate, ventral view; E - style, dorsal view; F, G - connective and aedeagus, dorsal and lateral view, respectively (after Duan et al., 2018a).
- Aedeagal shaft shorter and broader with dorsal surface flattened, troughlike or membranous, without short lateral preapical flanges (Fig. 4F); crown color variable but lateral preapical spots, if present, little or no larger than submedial spots......

7 Aedeagus with dorsal apodeme present and well sclerotized (Fig. 4B). Aedeagus without dorsal apodeme (Fig. 3H, I) ..................... Mattogrossus Linnavuori, 1959

8 Aedeagus apex enlarged or, if not, pygofer without toothlike ventral preapical process (Fig. 4A, B)

Amblysellus Sleesman, 1929

- Aedeagus apex not enlarged, pygofer usually with toothlike ventral preapical process (Fig. 4C-E)

Unerus DeLong, 1936

9 Gonopore large, on ventral surface of aedeagus preapically (Fig. 4F, G)

- Gonopore on dorsal surface of aedeagus or poorly defined (Fig. 6F, G) 12

10 Body relatively broad and depressed, head nearly four times as wide as median length in dorsal view (Fig. 7A), aedeagus only shallowly emarginate apically in ventral view (Fig. 4F) Toldoanus Linnavuori, 1954

- Body relatively narrow and cylindrical, head less than three times as wide as median length in dorsal view (Fig. 7B), aedeagus with gonopore preapical on ventral surface (Fig. 4H, I)... ...11
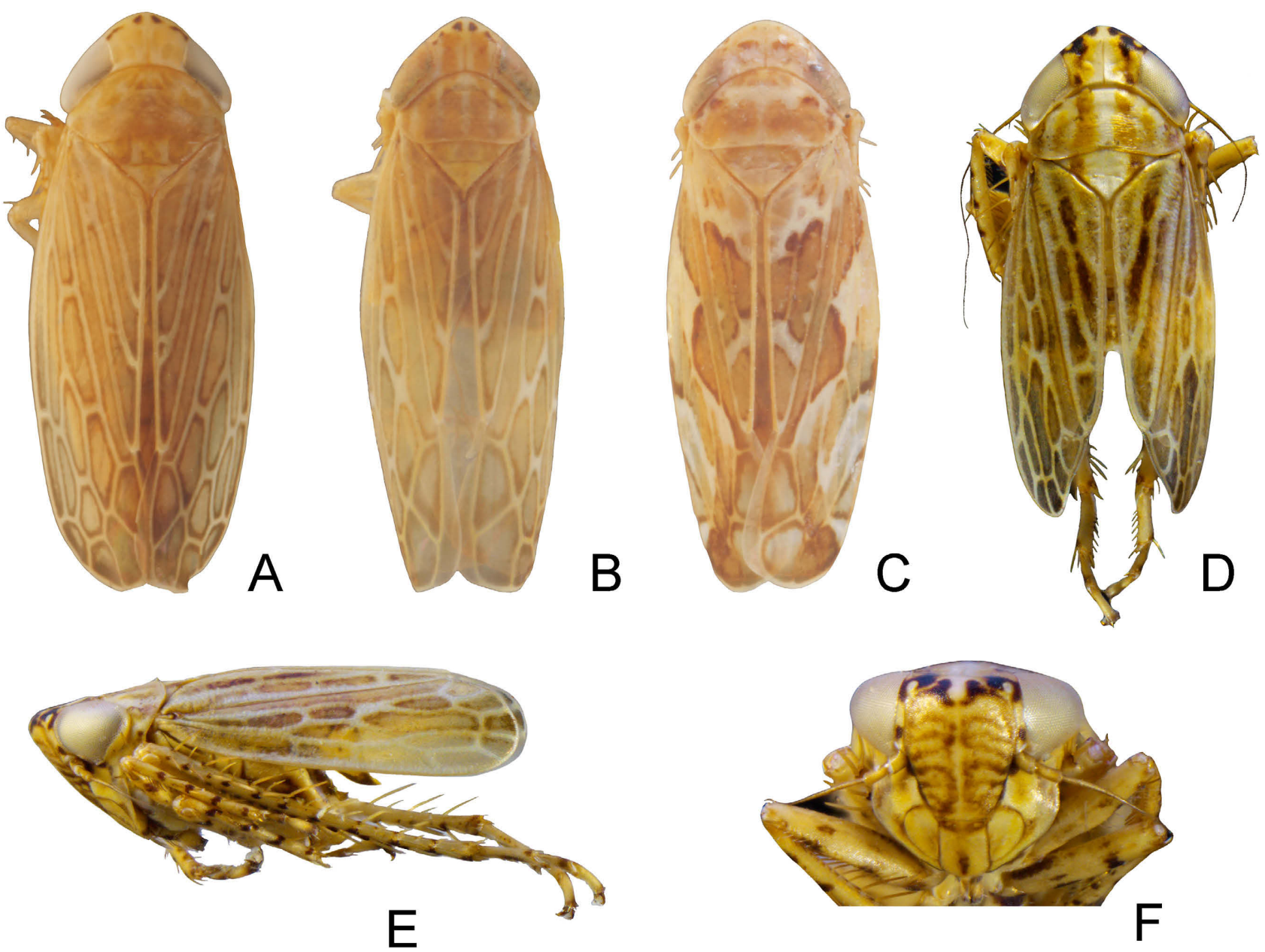

Fig. 7. A - Toldoanus marginellus; B - Reventazonia artrifrons Linnavuori, 1959; C - Sanctanus (Cruciatanus) dampfi DeLong \& Hershberger, 1946; D-F - Quaziptus chapini (holotype, male). A-D - habitus, dorsal view. E - habitus, lateral view; F - face. 


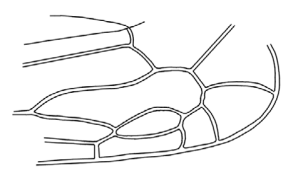

A

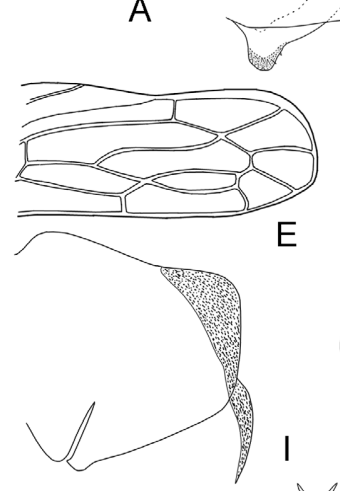

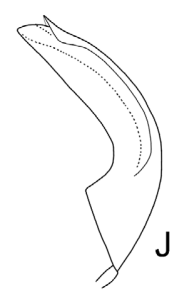
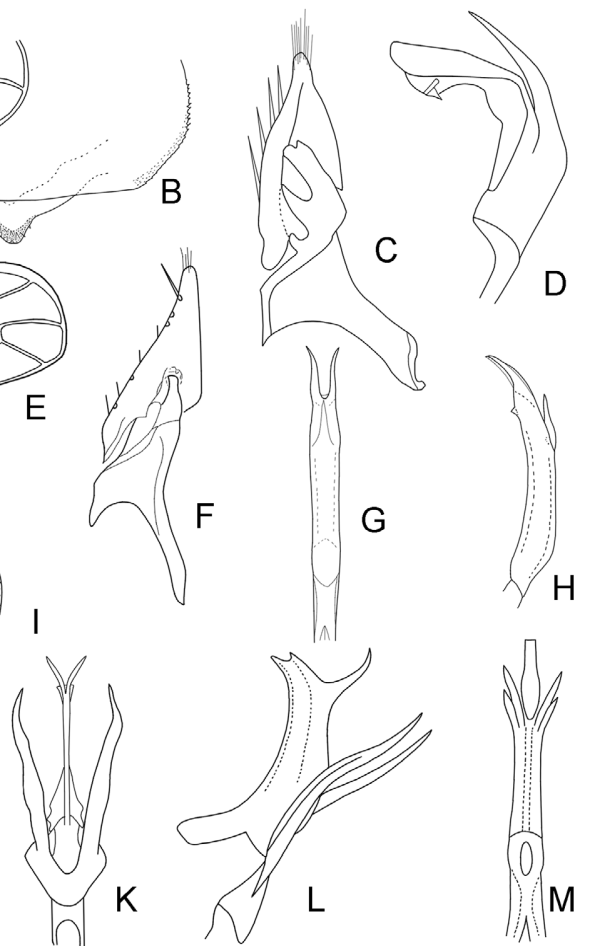

G
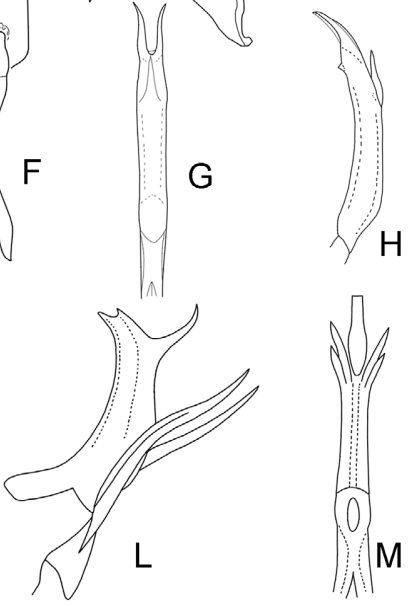

11

Fig. 8. A-D - Bolarga nigriloba Linnavuori, 1959 (after Linnavuori, 1959); E-H - Cruziella trispinosa Linnavuori \& DeLong, 1979 (after Linnavuori \& DeLong, 1979a); I, J - Tumupasa harpago Linnavuori, 1959 (after Linnavuori, 1959); K, L - Haldorus (Haldorus) capreolus Linnavuori, 1959 (after Linnavuori, 1959); M - Quaziptus chapini (after Kramer, 1965). A, E - apex of forewing; B - apex of male pygofer lobe, lateral view (without macrosetae); C, F - subgenital plate and style; D, H, J, L - aedeagus, lateral view; G, K, $M$ - aedeagus, ventral view; I - male pygofer lobe, lateral view (without macrosetae).

11 Aedeagus apex only shallowly emarginate in ventral view (Fig. 4H) Reventazonia Linnavuori, 1959

- Aedeagus with median longitudinal cleft occupying more than half length of shaft with gonopore at base of cleft (Fig. $4 \mathrm{~J})$ .. Limpica Cheng, 1980

12 Forewing usually with only two closed anteapical cells (Fig. 25A, B), preapical lobe of style usually sharply angulate (Fig. 26D)....... .. Graminella DeLong, 1936

- Forewing with three or more closed anteapical cells, preapical lobe of style blunt.

13

13 Dorsal coloration consisting of symmetrical spots and longitudinal stripes, without bold orange, brown or white bands (Fig. 5A-C) [Note: The type species of Nullamia DeLong, 1970 will also apparently key here, see below.]

Amplicephalus DeLong, 1926

- Dorsal coloration including contrasting white and orange or brown bands in addition to smaller spots (Fig. 7C)....

Sanctanus Ball, 1932

14 Aedeagus with single unpaired process arising preapically on ventral surface of shaft and extended distad (Fig. 8D); forewing with branches of vein $\mathrm{R}$ reflexed (Fig. 8A)

15

- Aedeagus with paired processes in various configurations (Fig. 20E, F); forewing with branches of vein R not reflexed (Fig. 19A-C)...

15 Forewing with posterior branch of R strongly reflexed, outer apical cell about half as long as adjacent apical cell; pygofer lobe with sclerotized process arising on dorsal margin and extended anteroventrad into genital capsule; subgenital plate

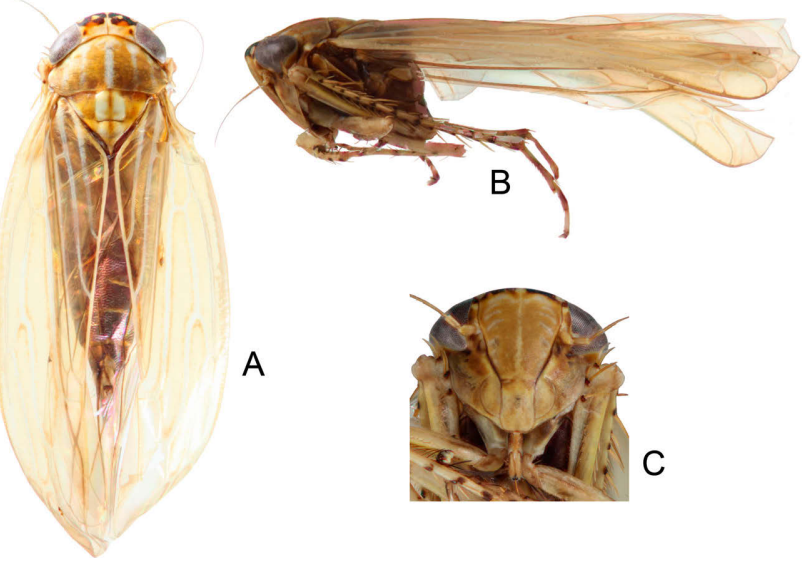

Fig. 9. Parandanus longistylus Duan, 2016. A - habitus, dorsal view; B - habitus, lateral view; C - face (after Duan et al., 2016a).

with dense group of macrosetae at apex (Fig. 8A-C) .....

Bolarga Oman, 1938

- Forewing with posterior branch of R only slightly reflexed, outer apical cell nearly as long as adjacent apical cell; pygofer lobe without sclerotized process; subgenital plate without dense group of macrosetae at apex (Fig. 8E, F) .

..Cruziella Linnavuori \& DeLong, 1979

16 Pygofer with one or more sclerotized processes (Fig. 8I) ......

Tumupasa Linnavuori, 1959

Pygofer without processes (Fig. 20A)

17

17 Aedeagus with well sclerotized dorsal apodeme at base, with at least one pair of processes arising near base of shaft and usually with additional paired processes (Fig. 8K, L) [Note: Nullamia bicornis Linnavuori \& DeLong, 1977 also keys here, see below.] . .Haldorus Oman, 1938

- Aedeagus without well sclerotized dorsal apodeme at base, processes usually arising distad of shaft midlength (Fig. 20E, F). 18
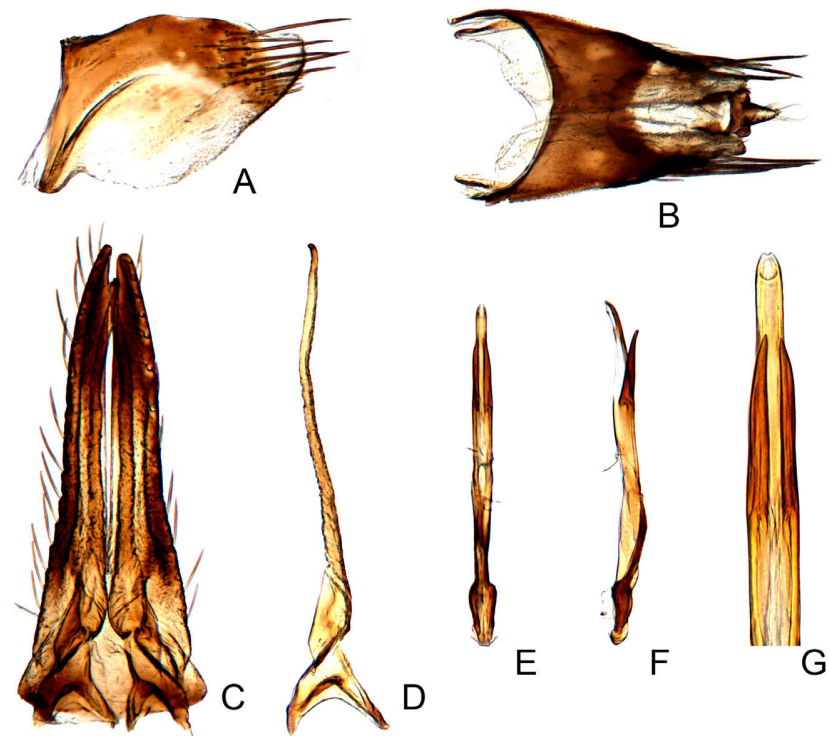

Fig. 10. Parandanus longistylus. A - male pygofer side, lateral view; $\mathrm{B}$ - male pygofer and segments $\mathrm{X}$ and $\mathrm{XI}$, dorsal view; $\mathrm{C}$ valve, subgenital plates and styles, ventral view; $D$ - style, dorsal view; E, F - connective and aedeagus, dorsal and lateral view, respectively; G - apex of aedeagus, dorsal view (after Duan et al., 2016a). 

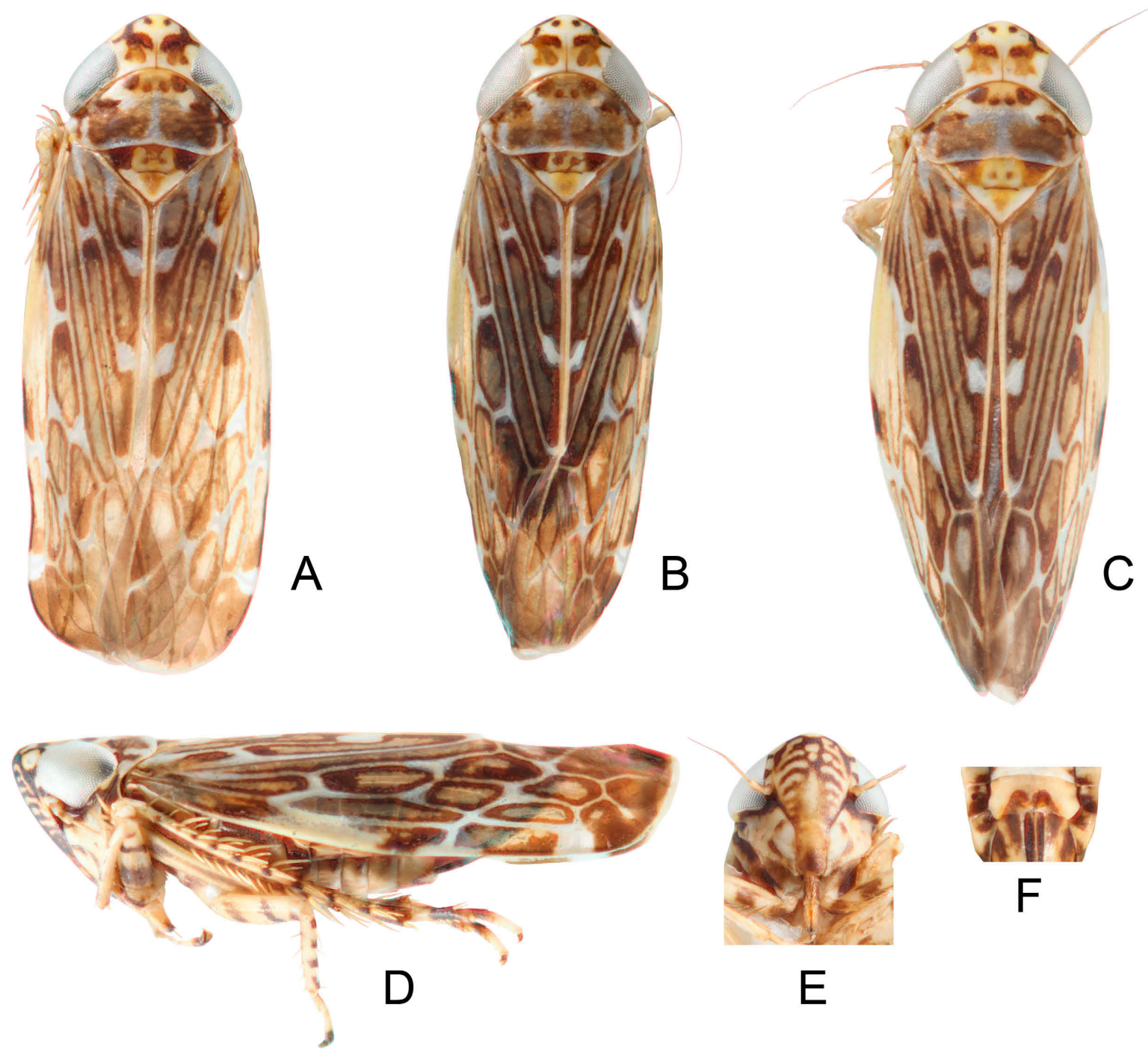

Fig. 11. Loreta (Loreta) ornaticeps Linnavuori, 1959 (A, B - male; C-F - female). A, B, C - habitus, dorsal view; D - habitus, lateral view; $\mathrm{E}$ - face; F - subapical part of female abdomen, ventral view (after Duan et al., 2016b).

18 Aedeagus with shaft tubular, little or no wider in ventral view than in lateral view (Fig. 20E, F).

19

- Aedeagus with shaft depressed, much wider in ventral view than in lateral view (Fig. 23I-L)...

21

19 Processes of aedeagus arising at apex, distad of gonopore and extended basolaterad (Fig. 20E, F) ......... Corrientesia gen. n.

- Processes of aedeagus arising preapically, basad of gonopore (Fig. 10E-G)...

20 Crown with anterior margin produced and bluntly angulate (Fig. 7D), body length $<4 \mathrm{~mm}$, aedeagus with two pairs of processes (Fig. 8M) ......................... Quaziptus Kramer, 1965

- Crown with anterior margin not or only weakly produced, rounded, body length $>6 \mathrm{~mm}$ (Fig. 9A) .

..Parandanus Linnavuori \& DeLong, 1976

21 Aedeagal processes arising from apex of shaft (Fig. 12F, G); dorsal color pattern including paired brown or black spots or bands (Fig. 11A-C).

Loreta Linnavuori, 1959

- Aedeagal processes arising from near midlength of shaft (Fig. 23I-L); dorsum without paired spots or bands (Fig. 22A, B)

22 Pygofer with distal process (Fig. 13A). Salnogia gen. $\mathrm{n}$

Pygofer without process (Fig. 18A, B)

23 Pygofer with lobes dorsally separated to base of segment IX, with dorsoapical distal digitiform process; aedeagus with pair of short lateral preapical flanges (Fig. 13A, B)

.Planicephalus Linnavuori, 1954

- Pygofer with lobes broadly connected by sclerotized tergite basally, with falcate ventral preapical process; aedeagus with pair of short dorsoapical projections (Fig. 13C-E)

Vicosa Linnavuori \& DeLong, 1978

24 Forewing with supernumerary crossveins (Fig. 14A, B)........ ................................................. Polyamia DeLong, 1926

- Forewing without supernumerary crossveins (Fig. 17A-E)...

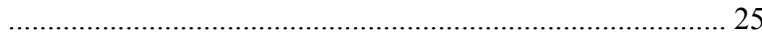

25 Aedeagus with three ventral longitudinal keels (Fig. 16A, B) ..Fusanus Linnavuori, 1955

- Aedeagus without ventral longitudinal keels (Fig. 18E, F). 26

26 Gonopore large, apical, well defined, apex of aedeagus blunt (Fig. 16E-G)

- Gonopore poorly defined, preapical, apex of aedeagus acuminate (Fig. 16C, D) ...... Picchuia Linnavuori \& DeLong, 1979

27 Aedeagus apex spatulate with depressed flange on each side of gonopore (Fig. 16E-G) ........... Spathifer Linnavuori, 1955

- Aedeagus apex not spatulate, without lateral depressed flange, paired lateral teeth sometimes present (Fig. 18E, F) Mendozellus Linnavuori, 1959 


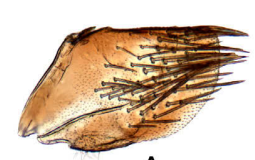

A

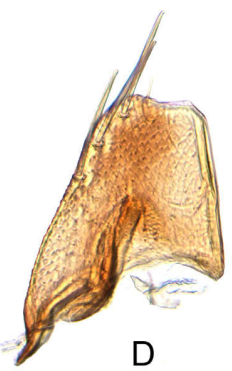

D
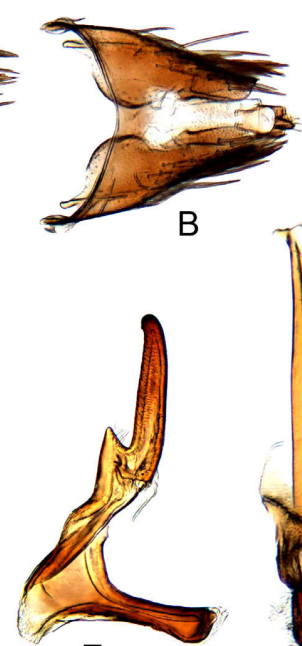

E
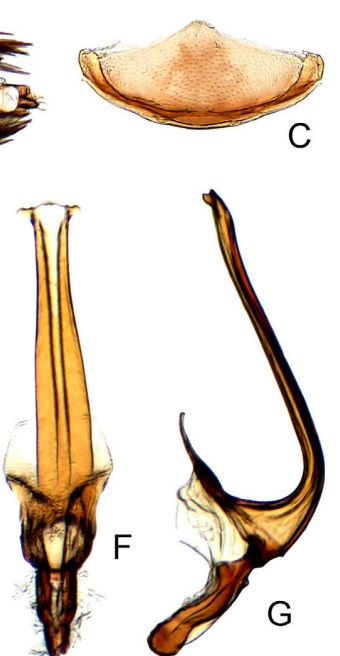

Fig. 12. Loreta (Loreta) ornaticeps. A - male pygofer lobe, lateral view; $\mathrm{B}$ - male pygofer and segments $\mathrm{X}$ and $\mathrm{XI}$, dorsal view; C valve, ventral view; D - subgenital plate, ventral view; E - style, dorsal view; F, G - connective and aedeagus, dorsal and lateral view, respectively (after Duan et al., 2016b).

\section{Genus Corrientesia gen. $\mathbf{n}$.}

ZooBank taxon LSID:

5CED069B-5CB1-4FF0-9E40-351010569DED

Type species: Corrientesia ochrescens sp. n.

Description. Coloration. Ground color off white, symmetrically marked with light to dark orange brown. Most of forewing veins white, bordered with dark brown, cells light brown. Hind tarsi with fuscous marks.

Morphology. Body robust, not depressed. Head much wider than pronotum, crown depressed, anterior margin distinctly angulate in dorsal view, slightly shorter than distance between eyes; ocellus small, less than half ocellar diameter from eye. Face moderately convex, length shorter than width; area between lateral frontal suture and eye strongly and evenly narrowed from antennal pit to crown

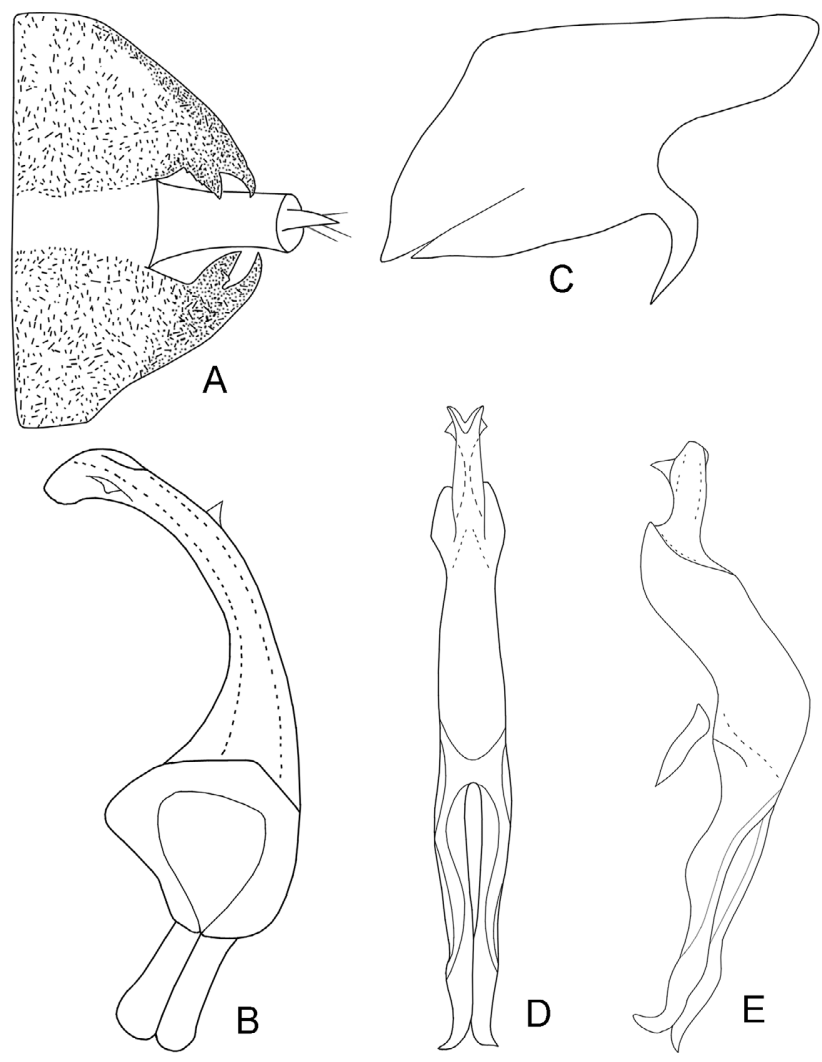

Fig. 13. A, B - Planicephalus flavicosta (Stål, 1862) (after Linnavuori, 1959); C-E - Vicosa bicornis Linnavuori \& DeLong, 1978 (after Linnavuori \& DeLong, 1978). A - male pygofer, dorsal view (without macrosetae); B, E - connective and aedeagus, lateral view; C - male pygofer lobe, lateral view (without macrosetae); $D$ - connective and aedeagus, ventral view.

margin, mesal margin of eye entire; frontoclypeus relatively narrow; antenna as long as width of head; clypeal sulcus poorly delimited or absent; anteclypeus tapered at base, but parallel sided through most of length, apex even with ventral margin of gena; lorum semicircular, narrower than anteclypeus, well separated from lateral margin of
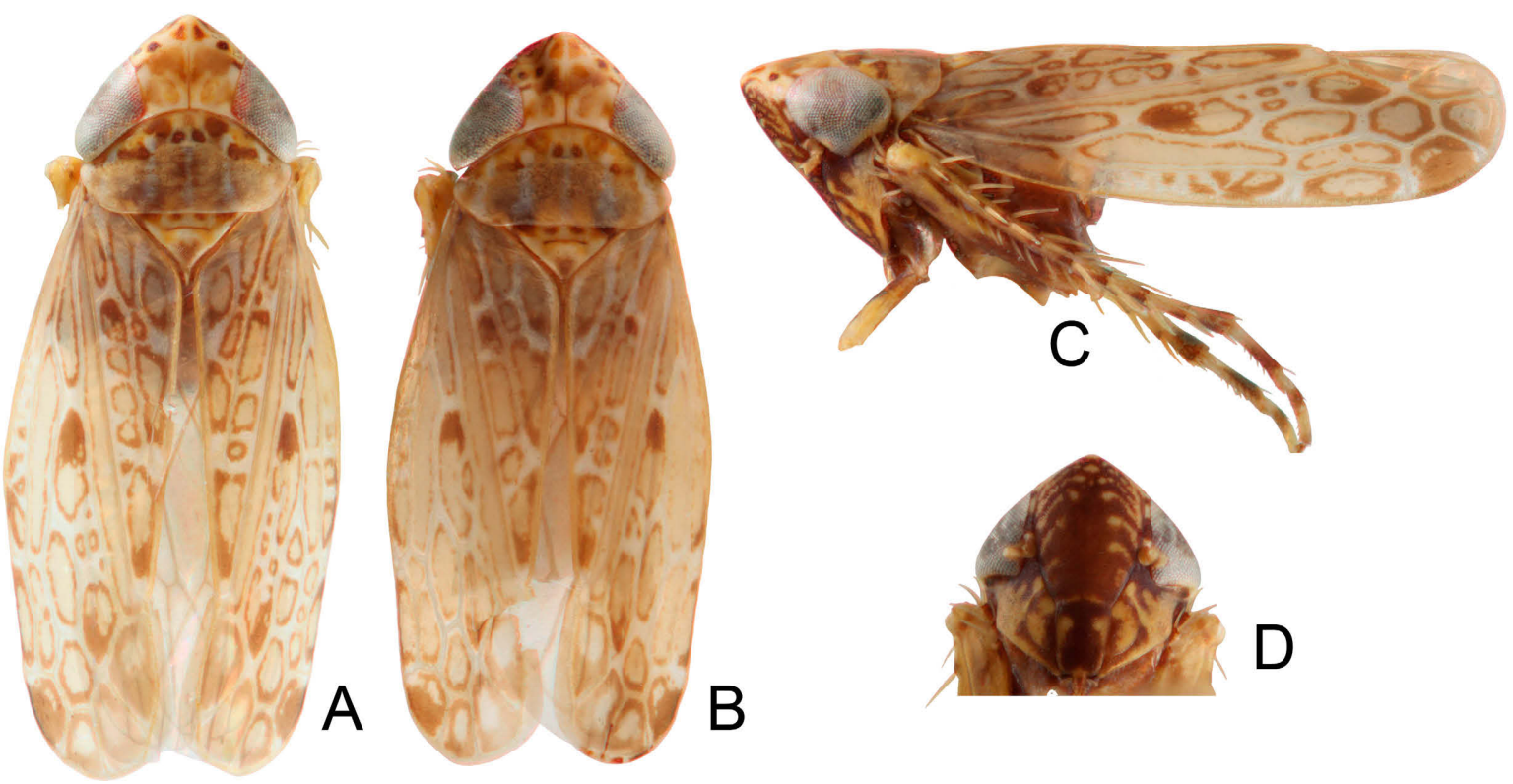

Fig. 14. Polyamia (Polyamia) weedi (Van Duzee, 1892). A, B - habitus, dorsal view; C - habitus, lateral view; D - face. 

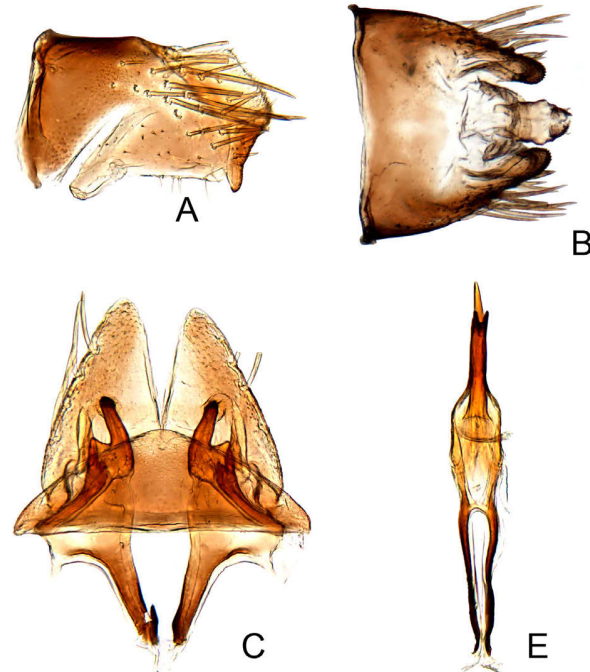

B

Fig. 15. Polyamia (Polyamia) weedi. A - male pygofer lobe, lateral view; $\mathrm{B}$ - male pygofer and segments $\mathrm{X}$ and $\mathrm{XI}$, dorsal view; $\mathrm{C}$ valve, subgenital plates and styles, ventral view; $D$ - style, dorsal view; E, F - connective and aedeagus, dorsal and lateral view, respectively.

face. Pronotum with lateral margin very short, eye nearly touching wing base. Forewing submacropterous in both sexes, apex obliquely truncate, appendix very narrow, vein R1 strongly reflexed, four closed anteapical cells present (central anteapical cell divided by crossvein), one or more supernumerary crossveins present in clavus and sometimes in corium. Front femur row AV with $\sim 7$ short, stout setae in basal half; row IC with $\sim 6$ fine pale setae. Front tibia dorsal macrosetae $1+4$. Hind femur macrosetal formula $2+2+1$. Hind tibial rows PD, AD and AV with ca. 8, 9 and 12 macrosetae, respectively; PD with one seta about half as long as macrosetae between successive macrosetae; $\mathrm{AD}$ with 1-4 short, stout setae between successive macrosetae. Hind tarsomere I with two well delimited plantar rows of stout, tapered setae; pecten with 4-5 platellae. Male and female abdominal tergite VIII with group of macrosetae near lateral margin.

Male genitalia. Pygofer well sclerotized dorsally in basal half; lobe without processes, with membranous posterodorsal section, and numerous long macrosetae restricted to well-sclerotized section of distal half. Segment X short and weakly sclerotized, without processes. Valve subtriangular, wider than long, posterior margin bluntly angulate. Subgenital plate triangular, apex sharply pointed, macrosetae arranged in uniseriate lateral row. Style with articulating arm short; preapical lobe distinct, angulate; apophysis moderately long and stout, digitiform. Connective shorter than aedeagus with arms slightly bowed laterad near midlength. Aedeagus with dorsal apodeme slender, platelike in posterior view; shaft slender, tubular, with pair of asymmetric apical processes; gonopore small but well delimited, preapical on ventral surface.

Female. Sternite VII with posterior margin broadly and shallowly concave (Fig. 21E). First valvula dorsal sculpturing imbricate, continuous with granulose ventral sculptured area near apex (Fig. 21A, B). Second valvula nearly uniform in width through most of length, dorsal margin

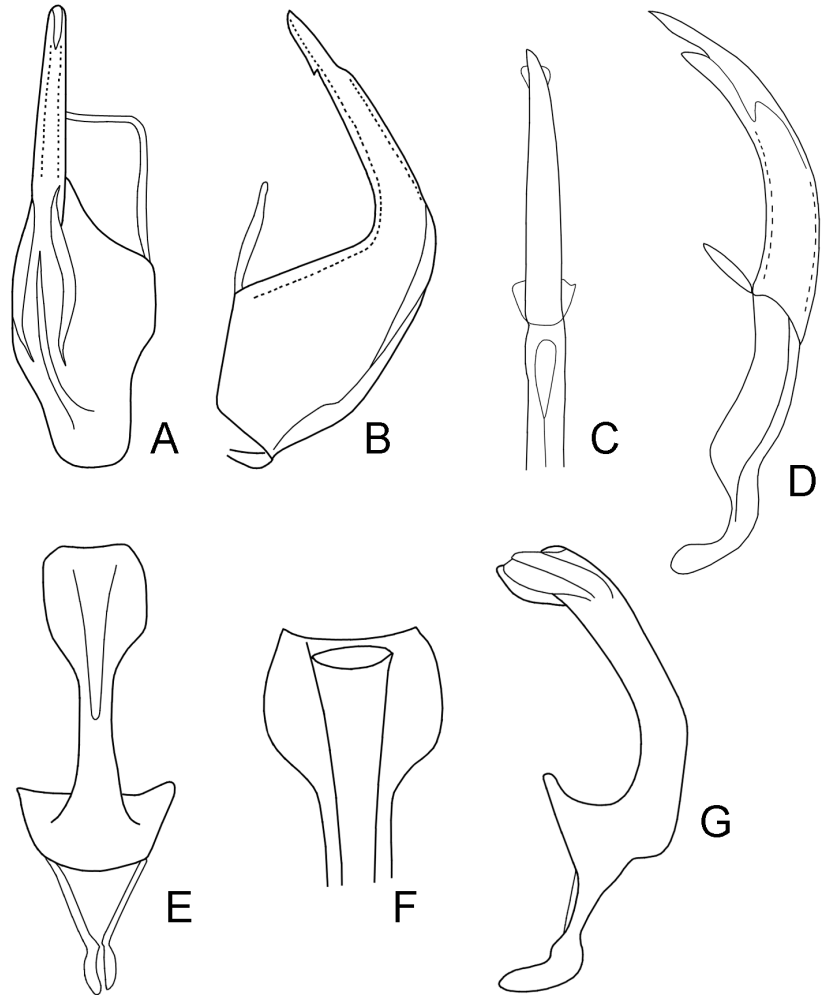

Fig. 16. A, B - Fusanus chacoensis (Linnavuori, 1955) (after Linnavuori, 1959); C, D - Picchuia pungens Linnavuori \& DeLong, 1979 (after Linnavuori \& DeLong, 1979a); E-G - Spathifer fuscatus Linnavuori, 1955 (after Linnavuori, 1959). A, C - aedeagus, ventral view; B - aedeagus, lateral view; D, G - connective and aedeagus, lateral view; $\mathrm{E}$ - connective and aedeagus, ventral view; $\mathrm{F}$ - apex of aedeagus, ventral view.

with sclerotized tooth in middle of unpigmented area near midlength, distal toothed section occupying less than half total length, with several evenly spaced conical teeth each separated by $2-5$ smaller teeth, apex somewhat attenuated (Fig. 21C-D).

Etymology. The genus name is based on that of the Argentine province from which the only known specimens were collected; gender feminine.

Distribution. Argentina.

Remarks. This genus is similar to the mostly North American genus Polyamia in having the forewing submacropterous with extra crossveins but differs in having the pygofer lobe with a poorly sclerotized posterodorsal section and the aedeagus with pair of long apical processes. Some species of the South American genus Loreta also have long, paired apical processes on the aedeagus, but the wings are fully developed, the aedeagal shaft is strongly depressed and straplike, and the forewing lacks supernumerary crossveins (Duan et al., 2016b). A group of macrosetae near the lateral margin of abdominal tergite VIII also occurs in Cortona but only in the female.

\section{Corrientesia ochrescens sp. $\mathbf{n}$.}

(Figs 19-21)

ZooBank taxon LSID:

2F32C545-F117-4821-8C4E-9C7A592EAB97 


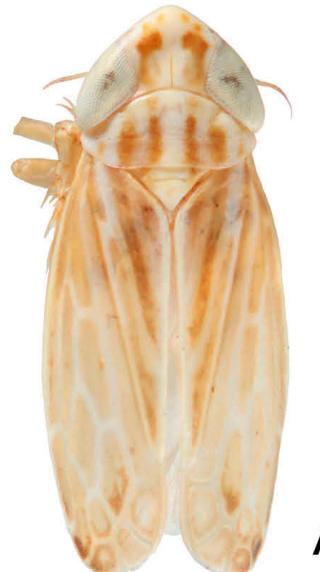

A
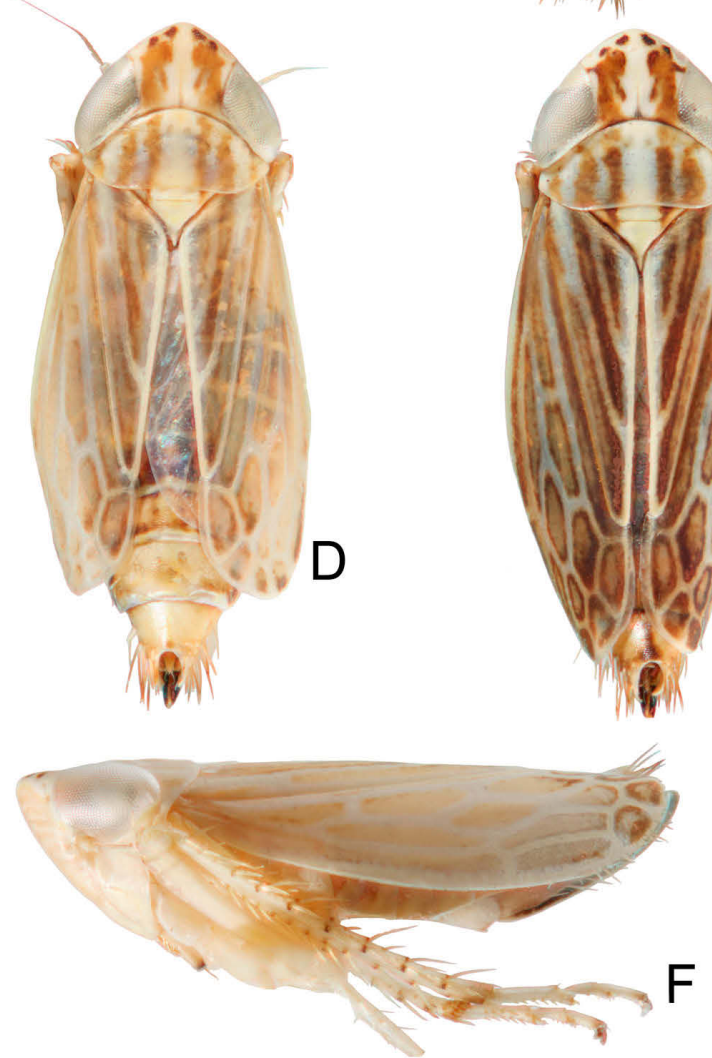

B
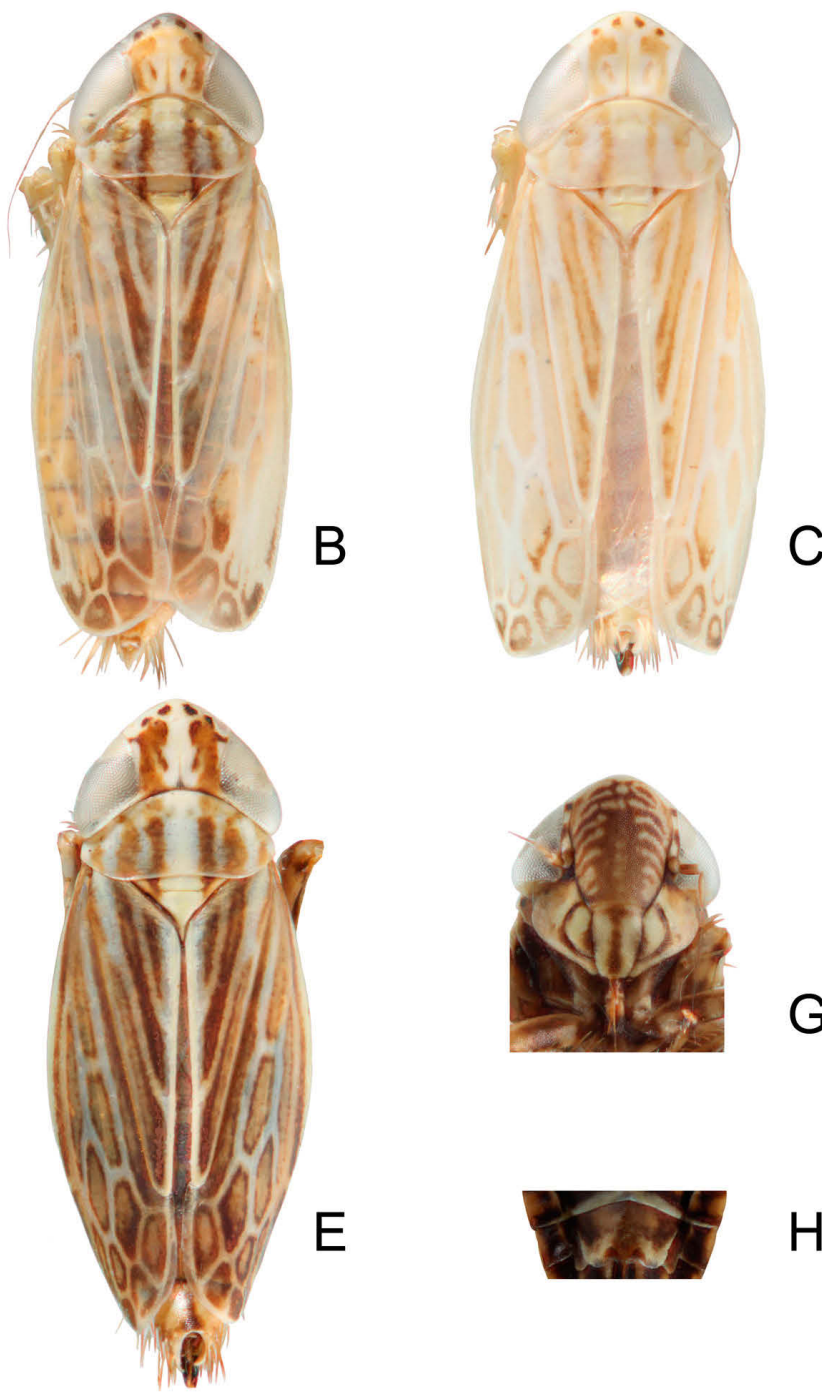

E

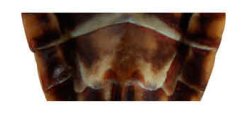

$\mathrm{H}$

Fig. 17. Mendozellus asunctia Cheng, 1980 (A, B - male; C-I - female). A-E - habitus, dorsal view; F - habitus, lateral view; G - face; $\mathrm{H}, \mathrm{I}-$ the end of female abdomen, ventral view ( $\mathrm{H}$ - without apex) (after Duan et al., 2017b).

Length. Male: $2.6-2.7 \mathrm{~mm}$; female: $2.8 \mathrm{~mm}$.

Description. Coloration. Vertex with brown marks (Fig. 19A, B). Forewing pale brown with veins bordered with brown or fuscous (Fig. 19A-C). Face mostly pale brown with paired white arcs corresponding to muscle scars of frontoclypeus (Fig. 19D).

Morphology. Forewing submacropterous, with four apical and three anteapical cells, central anteapical cell constricted and divided, inner anteapical cell closed basally, appendix narrow (Fig. 19A-C).

Male genitalia. Pygofer lobe with membranous posterodorsal area forming convex area in sclerotized section distally, caudal margin truncate (Fig. 20A, B). Subgenital plate lateral margin weakly concave (Fig. 20C). Style preapical lobe rectangular; apophysis slightly laterally curved (Fig. 20D). Aedeagus with atrium enlarged, ventral margin semicircular in lateral view; shaft evenly curved dorsad in lateral view, with 2-4 short asymmetrically arranged teeth on each side basad of gonopore; distal processes extended basolaterad, slightly less than half length of shaft (Fig. 20E, F).

Material examined. Holotype: $\hat{\sigma}$, Argentina: Corrientes, jet. Rt. 14 \& 119 [50 km WSW Pucheta], 304'35"S, 5759'57"W,

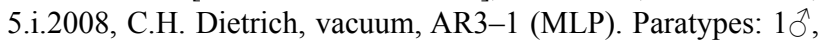
same data with holotype (INHS); $1 \hat{\delta}$, Argentina: Corrientes P. $\mathrm{N}$. Mburucuyà campground, $100 \mathrm{~m}, 28^{\circ} 0^{\prime} 56^{\prime \prime} \mathrm{S}, 58^{\circ} 2^{\prime} 15^{\prime \prime} \mathrm{W}$, 10.i.2008, C.H. Dietrich, vacuum, AR9-14 (INHS); $2 \hat{\jmath}, 1$, Argentina: Chaco P.N. Chaco, $70 \mathrm{~m}, 26^{\circ} 48^{\prime} 50^{\prime \prime} \mathrm{S}, 59^{\circ} 36^{\prime} 52^{\prime \prime} \mathrm{W}$, 

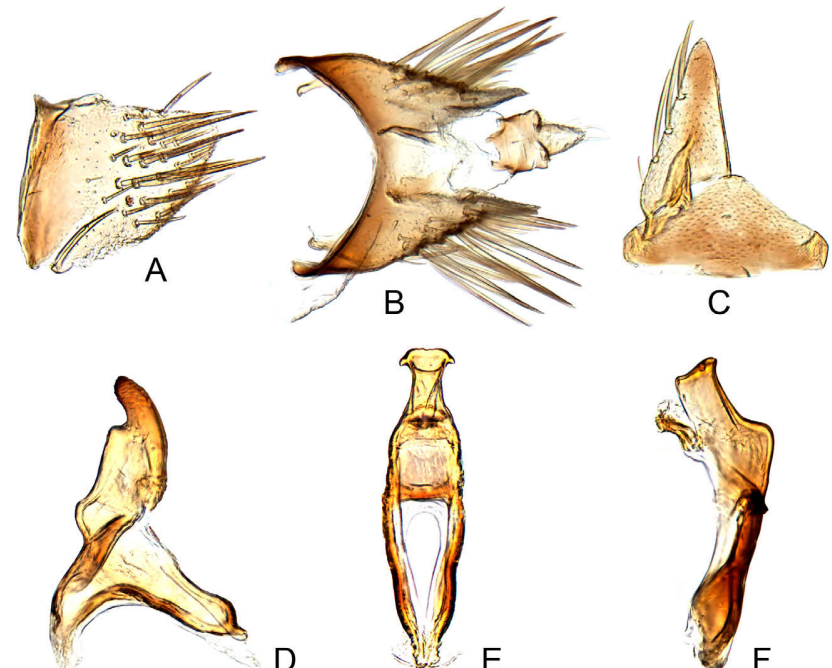

$D$

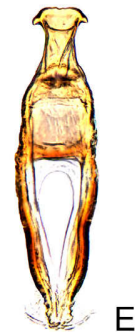

Fig. 18. Mendozellus asunctia. A - male pygofer lobe, lateral view; $\mathrm{B}$ - male pygofer and segments $\mathrm{X}$ and $\mathrm{XI}$, dorsal view; $\mathrm{C}$ - valve and subgenital plate, ventral view; D - style, dorsal view; E, F connective and aedeagus, dorsal and lateral view, respectively (after Duan et al., 2017b).
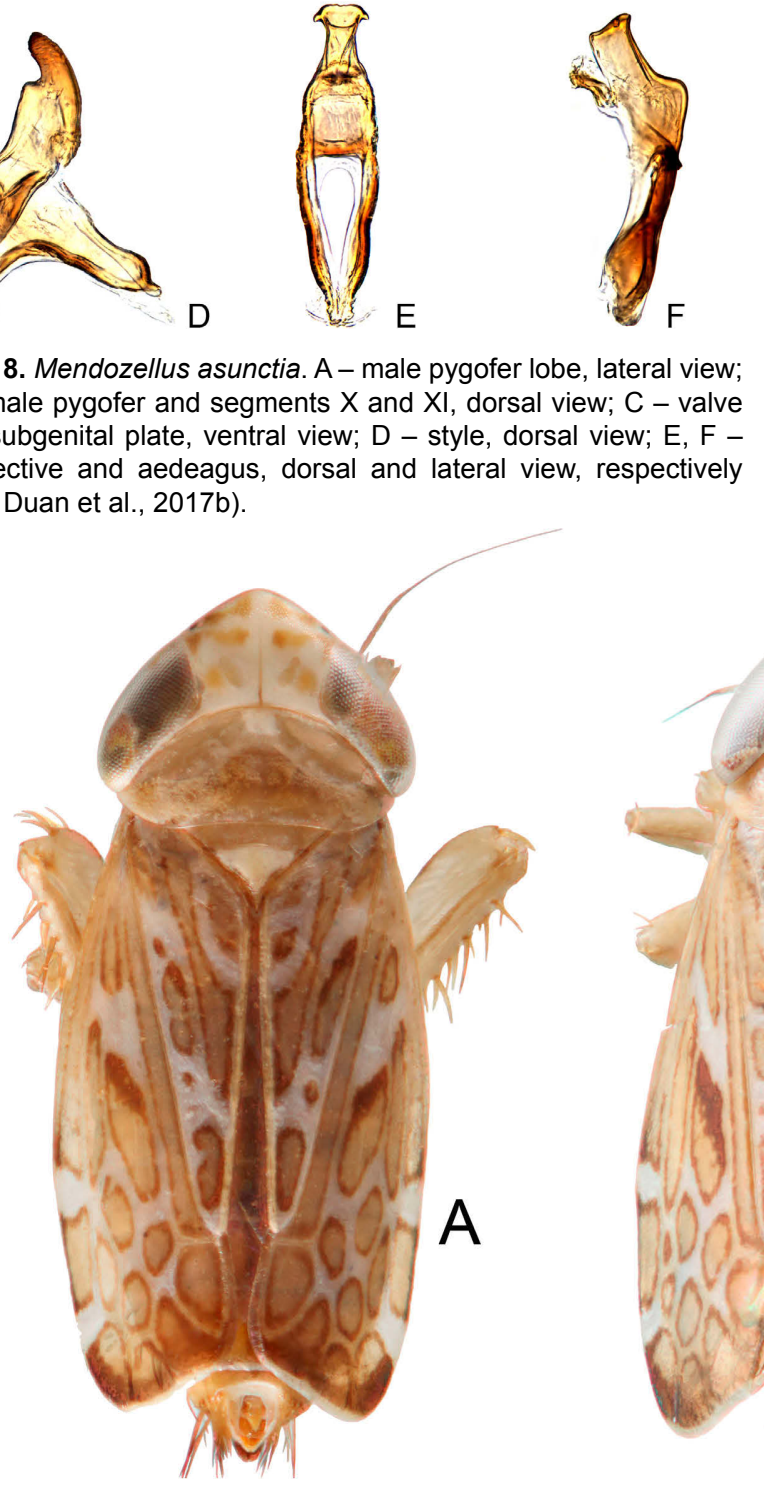

10.-13.i.2008, C.H. Dietrich et al., vacuum (INHS); 1 , , Argen-

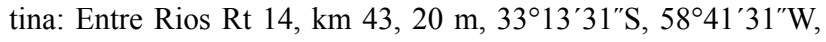
24.i.2008, C.H. Dietrich, vacuum, AR39-1 (INHS).

Type locality. $50 \mathrm{~km}$ WSW Pucheta, Corrientes (Argentina).

Etymology. The species name refers to the ochrescent dorsal markings.

Distribution. Argentina.

\section{Genus Salnogia gen. $\mathbf{n}$.}

ZooBank taxon LSID:

10BD9BC5-FCB5-407F-B965-96EAD1036E88

Type species: Salnogia fletcheri sp. n.

Description. Coloration. Dorsum mostly yellow, without paired spots or maculae, anterior margin or crown and most of thoracic venter and legs dark brown to black. Forewing veins pale, membrane translucent, infused with brown pigment. Abdomen mostly yellow; male pygofer and female segments VII, VIII and genital capsule dark brown.

Morphology. Body robust, depressed. Head wider than pronotum, crown anterior margin broadly angulate in dor-

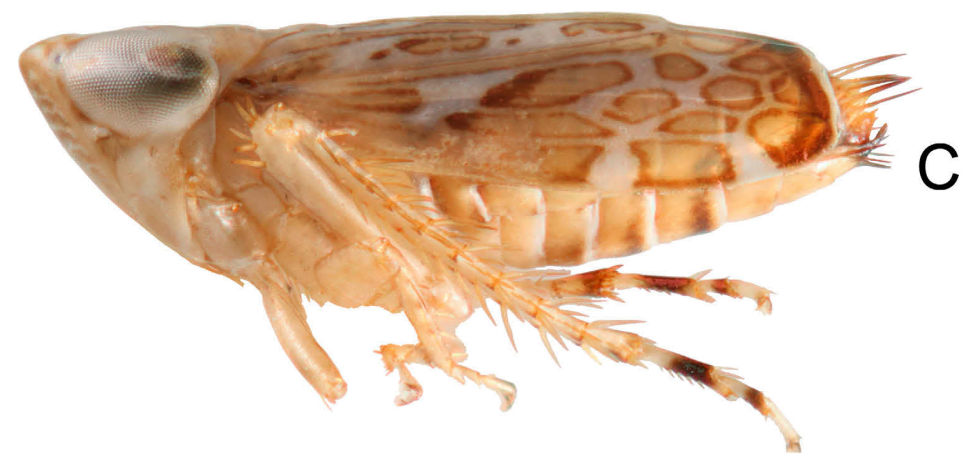

Fig. 19. Corrientesia ochrescens sp. n. (A-D - holotype, male; E - paratype, female). A, B - habitus, dorsal view; C - habitus, lateral view; $D$ - face; $E$ - the end of female abdomen, ventral view. 

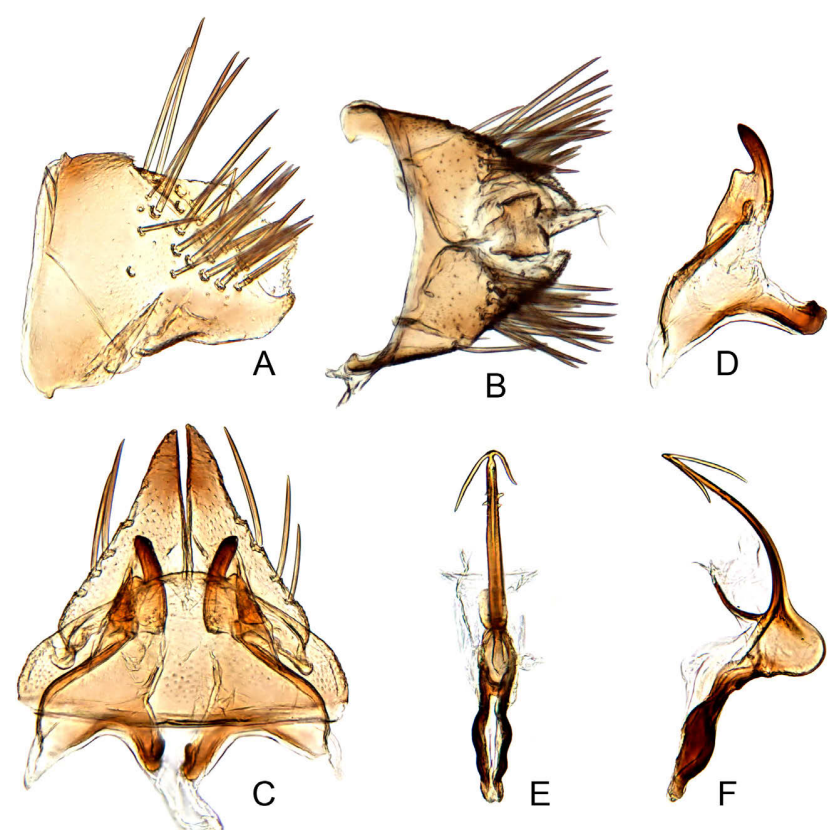

Fig. 20 Corrientesia ochrescens sp. n. (holotype, male). A - pygofer lobe, lateral view; $\mathrm{B}$ - pygofer and segments $\mathrm{X}$ and $\mathrm{XI}$, dorsa view; C - valve, subgenital plates and styles, ventral view; D style, dorsal view; E, F - connective and aedeagus, dorsal and lateral view, respectively.

sal view, shorter than distance between eyes; ocellus small, separated from eye by slightly more than one ocellar diameter. Face relatively flat, width greater than length; area between lateral frontal suture and eye slightly narrowed from

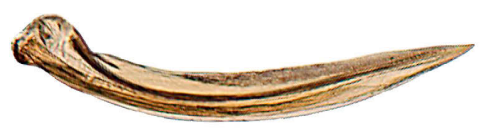

A

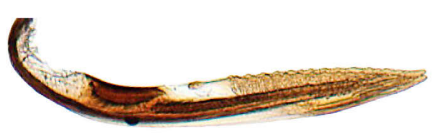

C

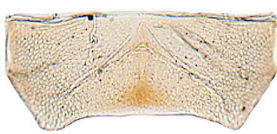

E

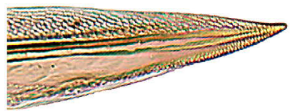

B

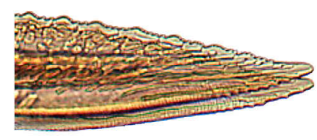

D

Fig. 21. Corrientesia ochrescens sp. n. (paratype, female). A - first valvula; $B$ - detail of first valvula; $C$ - second valvula; $D$ - detail of second valvula; $\mathrm{E}$ - sternite VII, ventral view.

antennal pit to crown margin, mesal margin of eye strongly emarginate adjacent to antennal base; antenna shorter than head width; frontoclypeus broad, weakly convex; clypeal sulcus prominent; anteclypeus tapering, extending to lower margin of genae; lorum semicircular, narrower than anteclypeus, well separated from lateral margin of face. Pronotum with lateral margin relatively long, eye well separated from wing base. Forewing fully developed, without extra crossveins, apex rounded, appendix narrow, R1 and R2 + 3 not reflexed, three anteapical cells present, inner cell closed or open basally, central cell rarely divided. Front femur row AV with several short, stout setae in basal half,

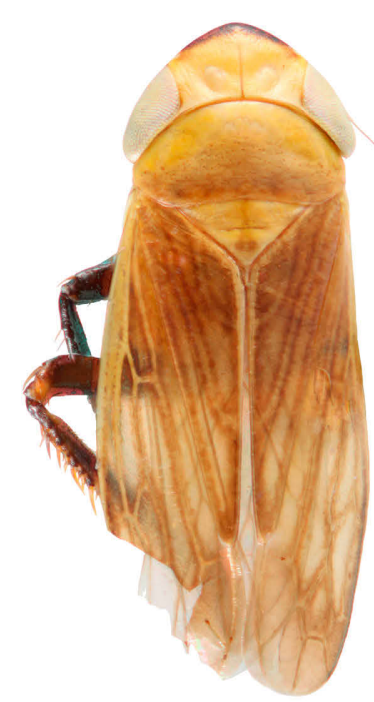

A

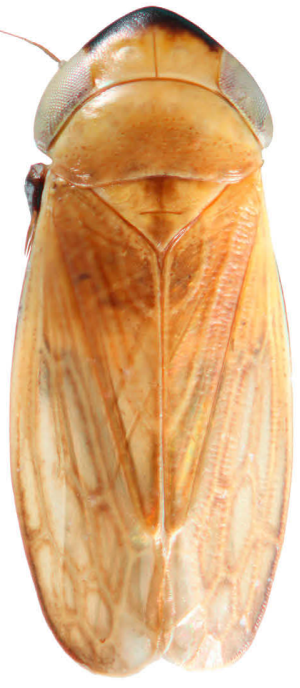

B

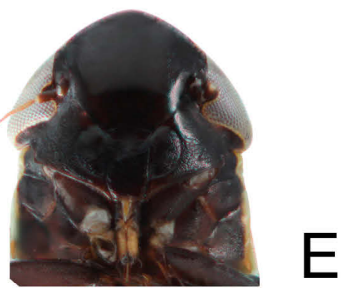

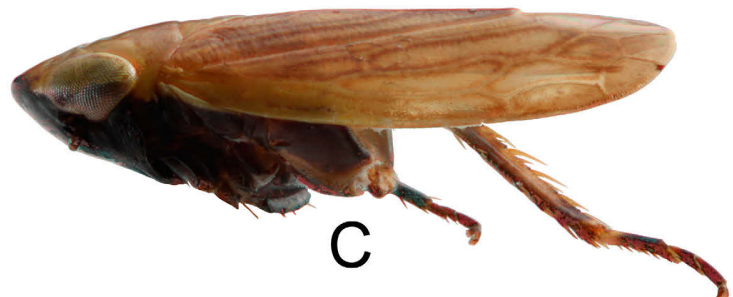
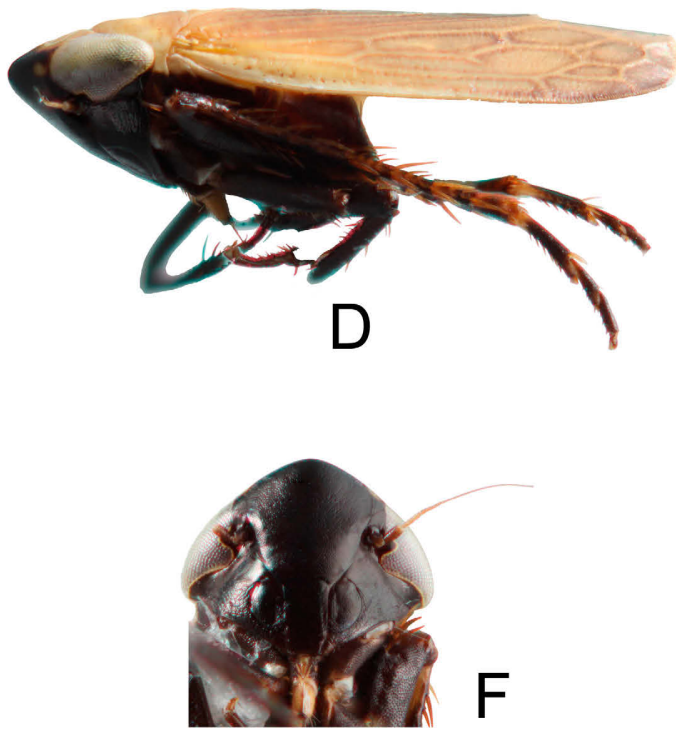

Fig. 22. Salnogia fletcheri sp. n. (A, C, E - holotype, male; B, D, F - paratype, male). A, B - habitus, dorsal view; C, D - habitus, lateral view; $\mathrm{E}, \mathrm{F}-$ face. 


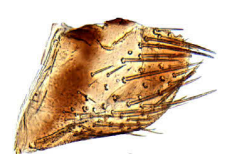

A

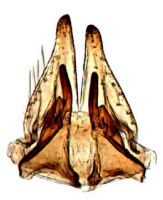

E
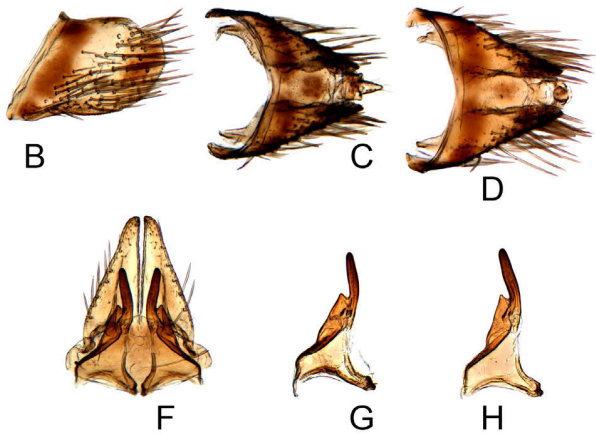

$\mathrm{H}$
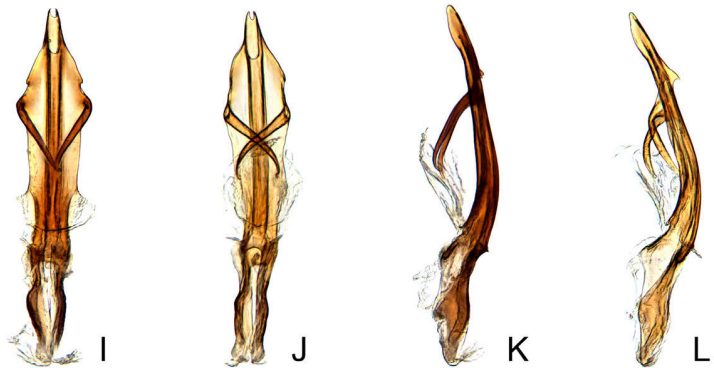

Fig. 23. Salnogia fletcheri sp. n. (A, C, E, G, I, K - holotype, male; $B, D, F, H, J, L$ - paratype, male). A, B - pygofer lobe, lateral view; C, D - pygofer and segments $\mathrm{X}$ and $\mathrm{XI}$, dorsal view; E, F - valve, subgenital plates and styles, ventral view; $\mathrm{G}, \mathrm{H}$ - style, dorsal view; $\mathrm{I}, \mathrm{J}$ - connective and aedeagus, dorsal view; $\mathrm{K}, \mathrm{L}$ - same, lateral view.

somewhat irregularly arranged; row IC with $\sim 8$ fine setae. Front tibia dorsal macrosetae $3+4$. Hind femur macrosetal formula $2+1+1$. Hind tibial rows $\mathrm{PD}, \mathrm{AD}$ and $\mathrm{AV}$ with ca. 9,10 and 11 macrosetae, respectively; PD with seta about half as long as macrosetae between successive macrosetae; AD with 1-4 short, stout setae between successive macrosetae. Hind tarsomere I with two well delimited plantar rows of stout, tapered setae; pecten with 4-5 platellae.

Male genitalia. Pygofer well sclerotized dorsally in basal two thirds; lobe without appendage, with numerous macrosetae scattered over distal two thirds. Segment X short and weakly sclerotized. Valve much broader than long, posterior margin bluntly angulate. Subgenital plate triangular, apex blunt, macrosetae uniseriate along lateral margin. Style with articulating arm moderately long; preapical lobe angulate; apophysis long and stout, digitiform. Connective shorter than aedeagus with arms slightly bowed laterad near midlength. Aedeagus without sclerotized dorsal apodeme, shaft strongly depressed, well sclerotized, with pair of long, slender subapical processes and paired lateral preapical flange, apex shallowly bifid; gonopore preapical on dorsal surface, well delimited.

Female. Sternite VII with posterior margin deeply concave (Fig. 24E). First valvula with dorsal sculpturing irregularly imbricate to granulose, continuous with ventral granulose sculptured area at apex (Fig. 24A, B). Second valvula somewhat broadened near midlength, toothed distal section occupying approximately half total length, with several evenly spaced conical teeth, each separated by two smaller teeth, apex somewhat attenuated (Fig. 24C, D).

Etymology. The generic name is an arbitrary combination of letters; gender feminine.

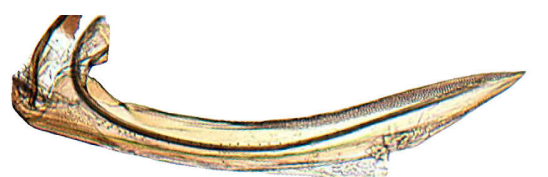

A
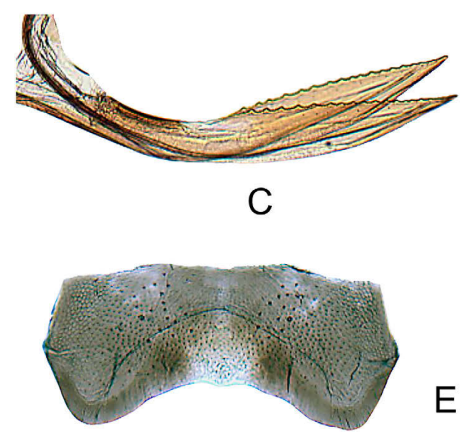

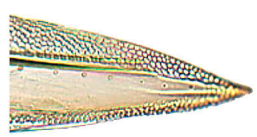

B

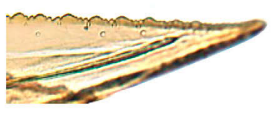

D
Fig. 24. Salnogia fletcheri sp. n. (paratype, female). A - first valvula; B - detail of first valvula; C - second valvula; D - detail of second valvula; $\mathrm{E}$ - sternite VII, ventral view.

Distribution. Argentina.

Remarks. This genus is unusual among Deltocephalini in its relatively depressed broad body form and also differs in the following combination of traits: (1) dorsum yellow, without paired spots, or stripes; (2) face and thoracic venter black; (3) forewing without extra crossveins; (4) aedeagus with a pair of subapical flanges and pair of long subapical appendages, apex bifid.

\section{Salnogia fletcheri sp. $\mathbf{n}$.}

(Figs 22-24)

ZooBank taxon LSID:

4E37BF76-13C7-46F7-8060-80AE888B115B

Length. Male: $2.9-3.0 \mathrm{~mm}$; female $3.3 \mathrm{~mm}$.

Description. Coloration. Fore margin of vertex dark, coronal suture pale brown. Mesonotum and scutellum with fuscous longitudinal band (Fig. 22A, B). Forewing brown with veins pale (Fig. 22A-D). Face dark (Fig. 22E, F).

Morphology. Forewing macropterous, with four apical and three anteapical cells, inner anteapical cell open or closed basally; appendix broad (Fig. 22A-D).

Male genitalia. Pygofer lightly sclerotized dorsally; lobe long, caudal margin round (Fig. 23A-D). Subgenital plate subtriangular, lateral margin concave, with macrosetae arising laterally (Fig. 23E, F). Style preapical lobe angulate; apophysis stout, long (Fig. 23G, H). Connective shorter than aedeagus. Aedeagal shaft apex shallowly split, slightly curved dorsad; subapical long appendages extended ventromesad to or beyond midline (Fig. 23I-L).

Material examined. Holotype: $\widehat{\partial}$, Argentina: Salta, Rt 9, km 1547 Los Nogales, $800 \mathrm{~m}, 24^{\circ} 48^{\prime} 19^{\prime \prime} \mathrm{S}, 65^{\circ} 0^{\prime} 47^{\prime \prime} \mathrm{W}, 19 . \mathrm{i} .2008$, C.H. Dietrich, vacuum, AR25-1 (MLP). Paratypes: $2 \hat{\jmath}, 1$, , same data with holotype (INHS).

Type locality. Salta (Argentina).

Etymology. This species is named for Dr. M.J. Fletcher who has made outstanding contributions to leafhopper classification.

Distribution. Argentina. 

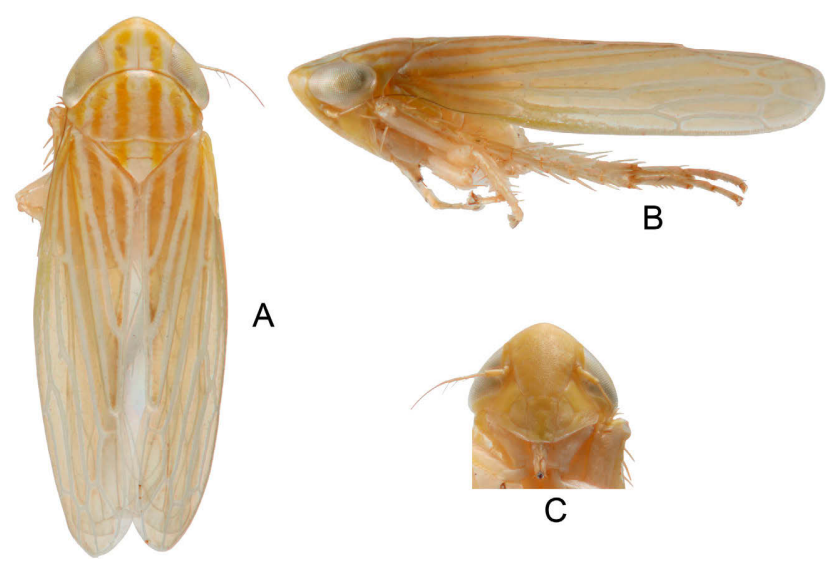

A

Fig. 25. Graminella schrocki sp. n. (holotype, male). A - habitus, dorsal view; $\mathrm{B}$ - habitus, lateral view; $\mathrm{C}$ - face.

\section{Genus Graminella DeLong, 1936}

Graminella DeLong, 1936: 218. Type species: Thamnotettix aureovittata Sanders \& DeLong, 1920.

Diagnosis. Crown usually with fuscous spots. Clypeal sulcus obscure. Forewing usually with only two closed anteapical cells. Preapical lobe of style usually sharply angulate. Aedeagus apex usually with distinct median longitudinal cleft in posterior or ventral view.

Distribution. North and South America, China.

Remarks. Until now, Graminella comprised 29 species including ten recorded from South America (Blocker et al., 1995). Below we describe a new species from Argentina, and propose a new synonymy for two other South American taxa belonging to this genus.

\section{Graminella schrocki sp. $\mathrm{n}$.}

(Figs 25-26)

ZooBank taxon LSID:

BB6B1827-98CE-4906-BC6D-2B4A3273AB82

Length. Male: $3.7 \mathrm{~mm}$ (female unknown).

Description. Coloration. Dorsum with pair of orange longitudinal submedial bands extended from apex of crown to forewing clavus, coronal suture light brown. Pronotum lateral pair of longitudinal bands extended across mesonotum to clavus (Fig. 25A). Forewing membrane opaquely sclerotized orange brown in basal half, veins white, distal part of wing pale translucent (Fig. 25A, B). Face mostly pale yellow (Fig. 25C). Venter of thorax and legs pale yellow, unmarked (Fig. 25B, C).

Morphology. Head wider than pronotum, crown depressed, anterior margin distinctly angulate in dorsal view, slightly shorter than distance between eyes (Fig. 25A); ocellus next to eye on anterior margin (Fig. 25B). Face relatively flat, length greater than width; frontoclypeus relatively narrow; clypeal sulcus not prominent; anteclypeus parallel-sided, apex even with lower margin of gena; lorum semicircular, narrower than anteclypeus, well separated from lateral margin of face (Fig. 25C). Forewing inner anteapical cell open basally, central anteapical cell not divided (Fig. 25A, B).
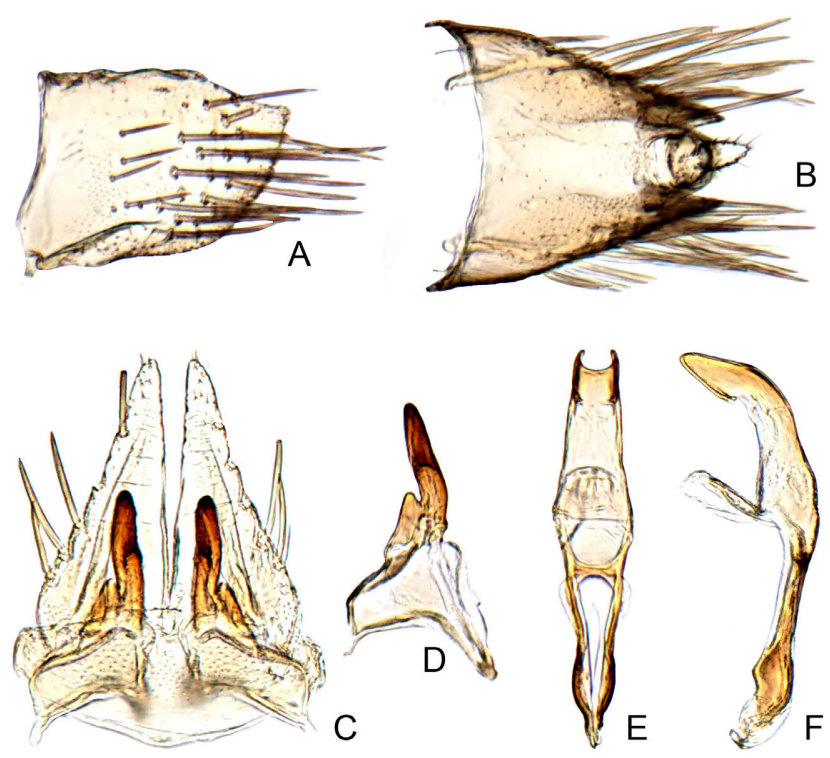

Fig. 26. Graminella schrocki sp. n. (holotype, male). A - pygofer lobe, lateral view; $\mathrm{B}$ - pygofer and segments $\mathrm{X}$ and $\mathrm{XI}$, dorsal view; C - valve, subgenital plates and styles, ventral view; D - style, dorsal view; E, F - connective and aedeagus, dorsal and lateral view, respectively.

Male genitalia. Pygofer lightly sclerotized dorsally; lobe relatively short, with numerous macrosetae in distal half, caudal margin angulate (Fig. 26A, B). Valve short, caudal margin obtuse angulate. Subgenital plate subtriangular, lateral margin weakly concave, apex acute (Fig. 26C). Style with articulating arm moderate long, preapical lobe angulate but weakly produced; apophysis stout, long, straight (Fig. 26D). Connective nearly as long as aedeagus. Aedeagal shaft poorly sclerotized dorsally, apex shallowly and widely split, curved $50^{\circ}$ dorsad, dorsal surface with small triangular subapical lobe on either side; gonopore apical but poorly delimited (Fig. 26E, F).

Material examined. Holotype: $\widehat{\sigma}$, Argentina: Tucumàn, rt 9

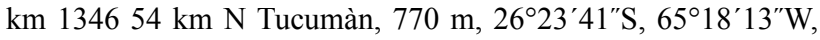
20.i.2008, C.H. Dietrich, vacuum, AR28-1 (MLP).

Type locality. Tucumàn (Argentina).

Etymology. This species is named for Dr. J.R. Schrock who has helped the senior author revise many manuscripts.

\section{Distribution. Argentina.}

Remarks. This species is somewhat similar to the North American species Graminella floridana DeLong \& Mohr, 1937 in coloration and the structure of the genitalia but differs in lacking dark spots on the anterior margin of the crown, having three pairs of longitudinal stripes on the pronotum, and in having the base of the aedeagus rounded and forming a continuous curve with the connective rather than sharply angulate ventrally in lateral view.

\section{Graminella stelliger (Berg, 1884)}

Athysanus stelliger Berg, 1884: 29.

Fusanus acristylus Cheng, 1980: 79, syn. n.

Remarks. Cheng's (1980) description and illustrations of $F$. acristylus indicate that this taxon is a synonym of $G$. stelliger, which was re-described and illustrated by Lin- 
navuori (1959). The apex of the aedeagus of this species varies somwhat in shape intraspecifically. The similarity of F. acristylus to Fusanus griseostriatus Linnavuori, 1955, noted by Cheng (1980) is superficial because the style of the former has a strongly and acutely produced preapical lobe, a feature characteristic of most Graminella species, including G. stelliger. Species of Fusanus have the style preapical lobe rounded.

\section{Limpica pallida (Linnavuori \& DeLong, 1979), comb. $\mathbf{n}$.}

Reventazonia pallida Linnavuori \& DeLong, 1979: 49.

Remarks. Limpica was originally established based on a single species, Limpica forcata Cheng, 1980, from Paraguay. Comparison of Cheng's (1980) original description and illustrations of the type species of the genus with those of Linnavuori \& DeLong's (1979) species clearly indicates that the two species are closely related. Species of Reventazonia have the gonopore situated on the ventral side of the shaft apex and extended basad, but the shaft apex is only slightly notched, not deeply divided as in Limpica. Based on the original descriptions and illustrations, L. pallida and $L$. forcata are identical in size and very similar in coloration but the latter differs in having the distal lobes of the aedeagus more slender and the subgenital plate with fewer macrosetae. The type specimens of both species need to be compared to determine whether the two taxa should continue to be treated as separate species.

\section{Genus Quaziptus Kramer, 1965, reinstated tribal placement}

Quaziptus Kramer, 1965: 29. Type species: Quaziptus chapini Kramer, 1965.

Remarks. This monotypic genus was originally unplaced to tribe within Deltocephalinae but Oman et al. (1990) listed it as belonging to Deltocephalini. Kamitani (1999) transferred the genus to Paralimnini and this placement was followed by Zahniser \& Dietrich (2013). The type species, $Q$. chapini, clearly has the connective linear and fused to the aedeagus, so the genus is here returned to Deltocephalini and may be separated from other South American genera by the key given above.

\section{Genus Nullamia DeLong, 1970}

Nullamia DeLong, 1970: 118. Type species: Nullamia fuegoensis DeLong, 1970.

Remarks. DeLong (1970) described this genus based on two male specimens of one new species ( $N$. fuegoensis) from southern Chile, placing it in Deltocephalinae, but not indicating a tribal placement. Linnavuori \& DeLong (1977) placed the genus in Deltocephalini and described a second species, N. bicornis, also from Chile. Although Linnavuori \& DeLong (1977) described N. bicornis as being similar to the type species of Nullamia "in general structure" published illustrations of the male genitalia of both species cast doubt on whether they are congeneric. DeLong's (1970) illustrations of the aedeagus of $N$. fuegoensis indicate that this species has a simple aedeagus, without processes and with a shallowly emarginate apex, whereas $N$. bicornis has a pair of long aedeagal processes arising near the midlength of the shaft and extended distad, with the shaft apex entire. As indicated in the above key, these two species will key to Amplicephalus and Haldorus, respectively. Unfortunately, DeLong's (1970) original description and drawings of $N$. fuegoensis are insufficient to establish its relationship to Amplicephalus with confidence and, although the male genitalia of $N$. bicornis resemble those of Haldorus, the latter genus has the forewings fully macropterous, rather than shortened as in Nullamia. Thus, further comparative study of both Nullamia species will be necessary to determine the status and relationships of the genus.

ACKNOWLEDGEMENTS. We express our sincere thanks to J.R. Schrock, Emporia State University, USA for editing an earlier version of this manuscript. We also thank J.N. Zahniser, US Department of Agriculture, Washington, DC, USA for assistance in identification and for checking and photographing the holotype of $Q$. chapini in the US National Museum collection. C.F. Austin also assisted in photographing specimens at INHS. This research is supported by the National Natural Science Foundation of China (31000968), Anhui Provincial Natural Science Foundation (1608085MC55), Anhui Provincial Outstanding Young Talent Support Plan Key Projects (gxyqZD2016036) and Anhui Provincial Colleges and Universities Natural Science Foundation (KJ2015A006), and by U.S. National Science Foundation Grant DEB-1639601. The senior author was supported by the National Scholarship Fund of China to pursue research at the Illinois Natural History Survey, Champaign, IL, USA, from August 2013 to August 2014.

\section{REFERENCES}

Blocker H.D., Fang Q.Q. \& Black W.C. 1995: Review of the Nearctic Deltocephalus-like leafhoppers (Homoptera: Cicadellidae). - Ann. Entomol. Soc. Am. 88: 294-315.

Cheng Y.J. 1980: New leafhopper taxa (Homoptera: Cicadellidae: Deltocephalinae) from Paraguay. - J. Kans. Entomol. Soc. 53: 61-111.

DeLong D.M. 1936: Some new genera of leafhoppers related to Thamnotettix. - Ohio J. Sci. 36: 217-219.

DeLong D.M. 1970: A new genus and species of deltocephaline leafhopper from southern Chile. - Ohio J. Sci. 70: 118-119.

Dietrich C.H. 2005: Keys to the families of Cicadomorpha and subfamilies and tribes of Cicadellidae (Hemiptera: Auchenorrhyncha). - Fla Entomol. 88: 502-517.

Duan Y.N., Dietrich C.H., WebB M.D. \& Zhang Y.L. 2016a: Review of the South American leafhopper genus Parandanus (Hemiptera: Cicadellidae: Deltocephalinae). - ZooKeys 562: 73-83.

Duan Y.N., Dietrich C.H. \& Zhang Y.L. 2016b: Review of the New World leafhopper genus Loreta (Hemiptera: Cicadellidae: Deltocephalinae: Deltocephalini). - Ann. Entomol. Soc. Am. 109: 495-501.

Duan Y.N., Dietrich C.H. \& Zhang Y.L. 2017a: Revision of the South American grassland leafhopper genus Cortona Oman (Hemiptera: Cicadellidae: Deltocephalinae: Deltocephalini) with description of four new species from Argentina. Zootaxa 4242: 359-371.

Duan Y.N., Dietrich C.H. \& Zhang Y.L. 2017b: Two new species of Mendozellus Linnavuori (Hemiptera: Cicadellidae: Delto- 
cephalinae: Deltocephalini) with redescription of Mendozellus asunctia Cheng. - Zootaxa 4232: 231-240.

DuAn Y.N. \& Dietrich C.H. 2018a: Notes on the Neotropical leafhopper subgenus Amplicephalus (Nanctasus) Linnavuori (Hemiptera: Cicadellidae: Deltocephalinae: Deltocephalini) with description of two new species. - Zootaxa 4455: 555-562.

DuAn Y.N. \& Dietrich C.H. 2018b: A new species of Polyamia DeLong (Hemiptera: Cicadellidae: Deltocephalinae: Deltocephalini) representing the first record of the genus from South America. - Zootaxa 4457: 557-567.

Freytag P.H. 1983: A new species of Unerus from Honduras (Homoptera: Cicadellidae). - Entomol. News 94: 187-190.

Kamitani S. 1999: The phylogeny of the genera in the tribes Deltocephalini, Paralimnini, and their allies (Homoptera: Cicadellidae: Deltocephalinae). — Esakia 39: 65-108.

Kramer J.P. 1965: New species of Deltocephalinae from the Americas (Homoptera: Cicadellidae). — Proc. Biol. Soc. Wash. 78: 17-31.

KRAMER J.P. 1971: North American deltocephaline leafhoppers of the genus Amblysellus Sleesman. — Proc. Entomol. Soc. Wash. 73: 83-98.

LinNAVUORI R. 1959: Revision of the Neotropical Deltocephalinae and some related subfamilies (Homoptera). Ann. Zool. Soc. Zool. Bot. Fenn. Vanamo 20(1): 1-370.

Linnavuori R. \& Delong D.M. 1977: The leafhoppers (Homoptera: Cicadellidae) known from Chile. - Brenesia 12/13: 163-267.
LinnaVuori R. \& DeLong D.M. 1978: Seventeen new species and three new genera of Central and South American Deltocephalini (Homoptera: Cicadellidae). - Brenesia 14-15: 195-226.

Linnavuori R. \& DeLong D.M. 1979a: New genera and species of the tribe Deltocephalini from South America (Homoptera: Cicadellidae: Deltocephalinae). —Entomol. Scand. 10: 43-53.

LinNaVuori R. \& DeLong D.M. 1979b: New species of leafhoppers from Central and South America (Homoptera: Cicadellidae, Deltocephalinae, Neobalinae, Xestocephalinae). — Entomol. Scand. 10: 123-138.

Oman P.W., Knight W.J. \& Nielson M.W. 1990: Leafhoppers (Cicadellidae): A Bibliography, Generic Check-list and Index to the World Literature 1956-1985. CAB International, Wallingford, $368 \mathrm{pp}$.

Webb M.D. \& Viraktamath C.A. 2009: Annotated check-list, generic key and new species of Old World Deltocephalini leafhoppers with nomenclatorial changes in the Deltocephalus group and other Deltocephalinae (Hemiptera: Auchenorrhyncha: Cicadellidae). - Zootaxa 2163: 1-64.

ZAHNiser J.N. \& Dietrich C.H. 2013: A review of the tribes of Deltocephalinae (Hemiptera: Auchenorrhyncha: Cicadellidae). - Eur. J. Taxon. 45: 1-211.

Zhang Y.L. 1990: A Taxonomic Study of Chinese Cicadellidae (Homoptera). Tianze Press, Yangling, Shaanxi, 218 pp.

Received March 29, 2018; revised and accepted September 13, 2018 Published online October 23, 2018 